\title{
TÜRKIYAT MECMUASI
}

\section{Yabancı Dil Olarak Türkçenin Öğretiminde Kullanılan Konuşma Etkinliklerinin Kültürlerarası İletişimsel Yaklaşım Bağlamında Değerlendirilmesi*}

\section{Evaluating Speech Activities Used in Teaching Turkish as a Foreign Language Using an Intercultural Communication Approach}

\author{
Kürşat İLGÜN ${ }^{1}$ (i), Muammer NURLU² (i)
}

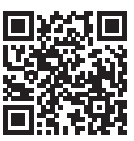

*Bu çalışma "Yabancı Dil Olarak Türkçenin Öğretiminde Kültürlerarası Yaklaşım Modeliyle Konuşma Becerisinin Geliştirilmesi" başlıklı doktora tezinden üretilmiştir.

\section{'Sorumlu yazar/Corresponding author: Kürșat İlgün (Doktora Öğrencisi), \\ Gazi Üniversitesi, Eğitim Bilimleri Enstitüsü/ Yabancı Dil Olarak Türkçenin Öğretimi Bilim Dalı, Ankara, Türkiye \\ E-posta: ilgunkursat@gmail.com \\ ORCID: 0000-0003-0969-6596 \\ ${ }^{2}$ Muammer Nurlu (Prof. Dr.), \\ Gazi Üniversitesi, Gazi Üniversitesi, Türkçe ve Sosyal Bilimler Eğitimi, Ankara, Türkiye \\ E-posta: mnurlu@gmail.com \\ ORCID: 0000-0003-3699-5794}

Başvuru/Submitted: 15.02.2021 Revizyon Talebi/Revision Requested: 03.02.2021

Son Revizyon/Last Revision Received: 22.02.202

Kabul/Accepted: 10.03 .2021

Online Yayın/Published Online: 24.05.2021

Atıf/Citation: Ilgun, Kursat ve Nurlu, Muhammer "Yabancı Dil OlarakTürkçenin

Öğretiminde Kullanılan Konuşma Etkinliklerinin Kültürlerarası lletişimsel Yaklaşım Bağlamında Değerlendirilmesi." Türkiyat Mecmuası-Journal of Turkology 31, 1 (2021): 225-257.

https://doi.org/10.26650/iuturkiyat.862236

\section{öz}

Yabancı dil öğretiminde dört temel dil becerisinin her biri için ayrı öğrenme sürecinin planlanması dil öğretimi açısından önemli bir husustur. Dili edinmenin veya öğrenmenin en temel göstergesinin konuşma becerisi olduğu ve bu beceriyi geliştirecek materyallerin de bu bağlamda en önemli araç olduğu düşünüldüğünde, bu materyallerin dil yeterliklerine uygun şekilde tasarlanması gerektiği söylenebilir. Dil ile kültür arasındaki bağ nedeniyle konuşma becerisi öğretiminde hedef dil ile ana dili arasında kültürlerarası iletişime yönelik oluşturulacak bir süreç, öğrenmeyi hızlandıracak ve kalıcı hâle getirecektir. Bu yaklaşımdan hareketle yabancı dil olarak Türkçe ders kitaplarına bakıldığında kültürlerarası yaklaşıma uygun konuşma etkinliklerinin belli bir düzende ve sırada yer almadığı ve kitaplarda sayısal ve oransal olarak farklar olduğu görülmektedir. Çalışmada İstanbul Yabancılar için Türkçe Öğretim Seti (iTÖS) ile Yedi Iklim Türkçe Öğretim Seti'nde (YiTÖS) yer alan B1 ve B2 düzeyi konuşma etkinlikleri, kültürlerarası iletişimsel yaklaşım bağlamında nitel olarak ele alınmış ve doküman analiziyle ortaya konan veriler karşılaştıııımıştır. Ayrıca etkinliklerin bu yaklaşıma uygun hazırlanmasına yönelik önerilerde bulunulmuştur.

Anahtar kelimeler: Yabancı Dil Olarak Türkçe, Konuşma Becerisi, Kültürlerarası Iletişimsel Yaklaşım

\section{ABSTRACT}

Planning a separate learning process for the four basic language skills in teaching foreign language is an important issue in this field. The materials should be designed in accordance with language competencies because the most important indicator of acquiring or learning language is the speaking skill, and the materials that are utilized to develop such skill are the most important tools in this context. The connection between language and culture requires the creation of a process for intercultural communication between the target language and native language in terms of speaking skills to accelerate and perpetuate learning. Based on this approach, when reviewing Turkish textbooks as a foreign language, the speaking activities that are in accordance with the intercultural approach are not in specific order, and there are numerical and 
proportional differences in such textbooks. In the study, B1- and B2-level speaking activities in Istanbul Turkish Teaching Set for Foreigners (ITTSF) and Yedilklim Turkish Teaching Set (YITTS) were qualitatively examined using an intercultural communicative approach, and data from the analysis of such documents were compared. In addition, suggestions were made to prepare activities using this approach.

Keywords: Turkish as a Foreign Language, Speaking Skill, Intercultural Communicative Approach

\section{EXTENDED ABSTRACT}

The basic indicator of learning a language is the speaking skill, and the materials that hone this skill are extremely important tools in this context. Such materials should be designed and applied according to language competencies. Due to the relationship between language and culture, a learning process should be initiated for intercultural communication between the target language and the source language in speaking skills, so that learning can be facilitated and rendered permanent. To this end, when reviewing Turkish textbooks in learning a foreign language, speaking activities that are suitable for the intercultural approach do not appear to be systematic, and discrepancies in rates can be observed.

In the study, B1- and B2-level speaking activities in the Istanbul Turkish Teaching Set for Foreigners (ITTSF) and Yedilklim Turkish Teaching Set were presented using the intercultural communicative approach. It aims to validate how many practices related to intercultural communicative approach were used in speaking activities, and what cultural elements were included in these practices, as well as to interpret them. In such textbooks, speaking activities, the way of transferring the approach, the cultural elements, and the numerical data of these elements are presented for this purpose.

The result of the analysis shows that the contents suitable for the intercultural communicative approach in the textbooks were generally formed by the unit title designed to support the content. The content suitable for such approach in some units covers all activities; however, any content suitable for the approach could not be found in other units. Traditions and Folklore was used 11 times in certain activities in specific textbooks, making it the most frequently used cultural element in activities related to intercultural communicative approach. Social Life and Geography and Location were used once in activities specified in textbooks, but they were the least used cultural elements in activities related to intercultural communicative approach. The fact that Social Life is one of the least used cultural elements can be considered a deficiency, especially when considering the language of functionality.

The results of the numerical analysis of the textbooks imply that ITTSF textbooks were designed in a more orderly and systematic manner in terms of distribution of cultural rates in activities suitable for cross-cultural communication as well as ratio of the number of activities. In ITTSF textbooks, the section entitled From Culture to Culture positively affected the rates and distributions.

According to the intercultural communicative approach model, predetermined cultural elements in a specific order in the materials that are used to develop speaking skills will facilitate learning. 


\section{Giriş}

Yabancı dil olarak Türkçe öğretilirken, yaşayan Türkçenin öğretilmesi önem arz etmektedir. Öğrencinin günlük hayatta iletişimini kolaylaştırmak için bu hususu göz önünde tutmak gerekir. Aksi hâlde öğrenci, toplumla ilişkisini sağlayamayacak ve dili öğrenme isteğinden vazgeçecektir. Bu durum dili öğretme hedefinin gerçekleşmesini zorlaştıracak ve öğrenim süreci sekteye uğrayacaktır. Bu nedenle sınıf içi etkinliklerde yapaylıktan uzak durulmalı ve günlük konuşmaya dayalı faaliyetler çoğaltılmalıdır. ${ }^{1}$ Dilin günlük kullanımına ait faaliyetlerin artırılması amacıyla özgün metinlerin kullanımına yer vermekte yarar vardır. Özgün metinler, dil öğrenicisinin hedef dilin (D2) kültürünü öğrenmesine ve günlük konuşma diline ait unsurları edinmesine önemli katkılar sağlar. ${ }^{2}$ Bu bağlamda hedef dilin öğretiminde, sık kullanılan kelimelerin öğretimi daha az kullanılan kelimelerin öğretimine göre daha etkilidir, çünkü bu kelimelerin iletişimde yaygınlığg söz konusudur. Bu durum anlama ve anlatma becerilerinin gelişiminde oldukça önemlidir. ${ }^{3}$

Yabancı dil öğretiminde dört temel dil becerisi olan dinleme, okuma, konuşma ve yazma eğitiminin birlikte verilmesi gerekmektedir. Çünkü dilin kullanım alanları, bu dört temel dil becerisinin her birine ihtiyaç duyar. Yabancı dil olarak Türkçenin öğretilmesi için hazırlanacak ders kitaplarının bu niteliklere uygun hazırlanması ve birinci üniteden itibaren bu özellikleri sağlaması gerekmektedir. Dil öğretim sürecinde basitten karmaşığa ilkesi belirlenmeli, verilen bilgiler ve yapılan etkinlikler öğrencinin günlük hayatta uygulayabileceği şekilde sunulmalıdır. Günlük hayata uygun olmayan bir öğretim süreci, öğrenciyi hedef kültürden ve dilden uzaklaştıracaktır. ${ }^{4}$

Öğrencinin yabancı dil öğretim sürecine en etkin şekilde katılabilmesi için uygun fiziki ortamın hazırlanmasından sonra eğitim sürecinde öğrencinin öğrendiklerini uygulamalarına olanak sağlanmalıdır. Dilin yapısının anlaşılabilmesi için uygulamaların planlanmasında, dört temel dil becerisinin etkin kullanılacağı yöntemlerin yanı sıra dilin kültürle birlikte verilmesi öğrenmeyi hızlandıracak ve kalıcı hâle getirecektir.

\subsection{Dil Öğretiminde Konuşma}

İnsanlar, toplumda kabul görmek ve var olmak için tüm sosyal ilişkilerini iletişim yoluyla ortaya koyar. Bu süreç doğumla beraber başlayıp hayatın sonuna kadar böyle devam eder. Toplumu ayakta tutan en önemli etkenin iletişim olduğu düşünüldüğünde, insanlar arasındaki anlaşmanın ve toplum yaşantısının sağlam temellere dayanması iletişimin sağlıklı yürümesiyle mümkün olacaktır. ${ }^{5}$

1 Abdurrahman Güzel ve Erol Barın, Yabancı dil olarak Türkçe öğretimi (Ankara: Akçağ Yayınları, 2013 ), 132.

2 Latif İltar, Türkçenin yabancı dil olarak öğretiminde kullanılan ders kitaplarındaki okuma metinlerinin farklı değişkenler açısından değerlendirilmesi (Doktora tezi, Gazi Üniversitesi, 2018), 30-31.

3 Neşe Kara Özkan, "Yabancı Di Olarak Türkçede Kelime Öğretimi Üzerine Bir Değerlendirme”, Baytarek Uluslararası Akademik Araştırmalar Dergisi 3/2 (2020), 132.

4 Muammer Nurlu, Türkçenin Yabancı Dil Olarak Öğretimi (Ankara: Kalem Kitap Yayınevi, 2019 ), 18.

5 Mehmet Temizkan, “Akran Değerlendirmenin Konuşma Becerisinin Geliştirilmesi Üzerindeki Etkisi”, Mustafa Kemal Üniversitesi Sosyal Bilimler Enstitüsü Dergisi 6/12 (2009), 92. 
"İnsanın başarısını, iş, eğitim ve özel hayatında büyük ölçüde etkileyen, yönlendiren faaliyet, bireyler ve birey-toplum arasında cereyan eden sözlü iletişim olarak adlandırabileceğimiz konuşmadır. İletişim ne kadar etkili, düzenli ve açık olursa aynı oranda başarı sağlanır." Sosyal bir varlık olan insan, yaşadığı çevreye ayak uydurmak için iletişim kurmak zorundadır. İletişimi sağlayan en önemli araç ise konuşmadır.

"Bireysel ve toplumsal hayatta önemli bir yer tutan konuşma; insanın okul ve iş hayatında başarı ya da başarısızlığını belirleyen etmenlerden de biridir. Bireyin diğer insanlarla dil yoluyla kurduğu iletişimin bir boyutunu oluşturan konuşma, bir duygu ve düşünce alışverişidir." Aynı zamanda dinleme becerisinden sonra en sık kullandığımız beceri konuşma becerisidir. Bu bağlamda dil edinim ve öğrenim sürecinde konuşma becerisinin kazandırılmasına yönelik tutumları geliştirmek önem arz etmektedir.

"Anlatma becerilerinden olan "konuşma” becerisinin eğitimi, Türkçe eğitiminde ihmal edilen konulardan biri olagelmiştir. Bu ihmal edilmişliğin sonuçları, ilköğretimden yükseköğretime

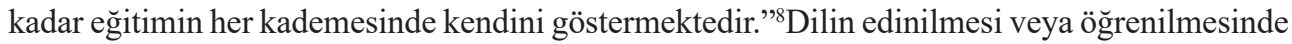
en belirgin gösterge konuşma becerisidir. İnsanın dili öğrenmesi önce konuşma becerisiyle kendini gösterir. Bu bağlamda yabancı dil öğrenmede oluşturulacak program ve materyallerin bu ihmali giderecek şekilde tasarlanması gerekmektedir.

"Konuşma becerisinin kazandırılması ve geliştirilmesinde işlenecek konunun içeriği, öğrencilerin seviyeleri, sınıf ortamının uygunluğu vb. özelliklere bakarak en uygun yöntem ve tekniklerin kullanılması gerekir." Ders kitaplarında yer alan konuşma materyallerinin geliştirilmesi ve yenilenmesi tüm bu hususlar dikkate alınarak ortaya konmalı ve geliştirilen materyaller sınıf sayıları, dil gruplarının çeşitliliği ve fiziki ortama göre esnetilebilmelidir.

\subsection{Dil ve Kültür}

İnsanlar, geçmişten günümüze toplu olarak yaşamış ve toplumu oluşturmuştur. Oluşan toplum ise yaşantıların sonucunda kültürü meydana getirmiştir. Kültürün oluşmasında ve geleceğe aktarılmasında en önemli etken iletişimdir. Bu nedenle dil ve kültür arasındaki bağ, yabancı dil öğretiminde üzerinde durulması gereken önemli bir konudur. ${ }^{10}$ Dil ile kültür arasındaki bağa bakıldığgnda, kültürün en önemli taşıyıcısının dil olduğu görülmektedir. Dil, kültürü muhafaza eden ve geliştiren aynı zamanda onu değiştiren en belirgin etmendir. Kültürün

6 Mehmet Kurudayığlu, "Konuşma Eğitimi ve Konuşma Becerisini Geliştirmeye Yönelik Etkinlikler" TÜBARXIII (2003), 288.

7 Fahri Temizyürek, "İlköğretim ikinci kademede konuşma becerisinin geliştirilmesi” Ankara Üniversitesi Eğitim Bilimleri Fakültesi Dergisi 40/2 (2007), 118.

8 Yusuf Doğan, "Konuşma Becerisinin Geliştirilmesine Yönelik Etkinlik Önerileri”, Türk Eğitim Bilimleri Dergisi $7 / 1$ (2009), 186.

9 Ali Göçer, “Türkçenin Yabancı Dil Olarak Öğretiminde Konuşma Becerisinin Kazandırılması”, Trakya Üniversitesi Sosyal Bilimler Dergisi 17/2 (2015), 24.

10 Adem İşcan ve Tufan Yassıtaş, "Yabancı dil olarak Türkçe öğretimi ders kitaplarında kültür aktarımı: Yedi iklim Türkçe öğretim seti örneği (B1-B2 düzeyi)”, Aydın Tömer Dil Dergisi 3/1 (2018), 49. 
varlığını sürdürebilmesi için dilin varlığına ihtiyaç duyulmaktadır. Bu bağlamda kültürün geleceğe, doğru aktarılması açısından dilin yapısının muhafaza edilmesi önem arz etmektedir. ${ }^{11}$

Aynı dili konuşan farklı etnik gruplar, kültürel anlamda da ortak unsurları paylaşırlar. Dilini kaybeden kültür grupları ise kültür unsurlarını da zamanla kaybeder ve başka bir dile ve kültüre geçiş yaparlar. Dolayısıyla kültürü korumanın yolu, dilin yapısını muhafaza etmekle mümkündür. Dilin yapısını muhafaza etmek için ise dil ile kültür arasındaki ilişkiyi hesaba katarak dil öğretimini planlamak gerekmektedir.

Ana dili (D1), yabanc1 dil öğrenimi doğrudan etkileyen bir husustur. Edinilmiş olan ana dili, yabancı dilin öğrenilmesini içermekte olduğu benzerlikler ve farklılıklar sebebiyle kolaylaştırabilmekte veya zorlaştırabilmektedir. ${ }^{12}$ Dil öğretimi, sadece o dilin yapısını öğretmek olmamalı aynı zamanda hedef dilin kültürünü de öğretmek olmalıdır. Bu nedenle hedef kültüre ait unsurlar, dil ögretiminde etkin kullanılmalı ve bu iki unsur birbirinden bağımsız düşünülmemelidir. Dil nasıl kültürün taşıyıcılığını üstlenmişse, kültür de dil öğretimi bağlamında belirleyici bir görev üstlenmiştir. ${ }^{13}$ Ayrıca dilin gücü kullanılarak o dili millî bir marka yapmak ve bunu kullanmak mümkündür. ${ }^{14}$

\subsection{Konuşma Becerisinin Geliştirilmesinde Kültürlerarası Yaklaşımın Önemi}

Dil öğretiminde amaç, dilin en kalıcı şekilde öğrenciye aktarılmasıdır. Bu kalıcılığı sağlamak için çeşitli yöntem ve teknikler kullanılır ve bu yollar eğitim sürecinde geliştirilip değiştirilebilir. Bu süreçte öğretme amacını gerçekleştirmek için öğrencinin hedef dile ait kültürel unsurlardan değer yargılarını, sosyal yapılarını ve geleneklerini benimsemelerine olanak sağlamak faydalı olacaktır. Ayrıca bu süreçte öğrencinin hedef kültür ile kaynak kültür arasında bir bağ kurmasına olanak sağlanmalıdır. Bu sayede hedef dili öğrenme süreci kolaylaşacak ve öğrenme kalıcı hâle gelecektir. ${ }^{15}$

Yabancı dil öğretiminde kültür aktarımını sağlamak, dili öğrenen için topluma uyum sağlamak için en iyi yoldur. Topluma uyum sağlamak ve toplumla iletişimi diri tutmak, dili öğrenmede akademik öğrenmeden daha etkili olacaktır. ${ }^{16}$ Yabancı dil öğretiminde, hedef kültürün aktarımı yapılırken hangi unsurların ön plana çıkacağını belirlemek gerekir. Kültür kavramının çok geniş bir alanı kapsadığı düşünüldüğünde, kültürel alanların belirlenme

11 Ahmet Demir ve Fatma Açık, "Türkçenin Yabancı Dil Olarak Öğretiminde Kültürlerarası Yaklaşım ve Seçilecek Metinlerde Bulunması Gereken Özellikler”, Türklük Bilimi Araştırmaları 30 (2011), 53.

12 Latif İltar, "Dil Edinimi, Dil Öğrenimi/Öğretimive Dil EğitimiÜzerineTartışmalar”, Boylu, Emrah, İltar Latif. (Ed.) Yabancı Dil Olarak TürkçeÖğretimiPolitika, Program, YöntemveÖğretimiçinde (Ankara: PEGEM, 2019), 10.

13 Emrah Boylu, "Dil-Kültür İlişkisi ve İranda Türkçe Öğretime Etkisi”, Karamanolu Mehmet Bey Üniversitesi Sosyal ve Ekonomik Aratirmalar Dergisi 4 (2014), 20.

14 Cihat Burak Korkmaz, "Yumuşak Güç Kaynağı Bağlamında Yabancı Dil Olarak Türkçenin Öğretimi”, Bayterek Uluslararast Akademik Araştırmalar Dergisi 3/2 (2020), 80, erişim 1 Ocak 2021, DOI:10.48174/buaad.820640

15 Alparslan Okur ve Funda Keskin, "Yabancılara Türkçe öğretiminde kültürel ögelerin aktarımı: İstanbul Yabancılar İçin Türkçe Öğretim Seti Örneği”, International Journal of Social Science Volume 6 Issue 2 6/2 (2013), 1624.

16 Yusuf Uyar, Türkçe Öğretiminde Kültür Aktarımı ve Kültürel Kimlik Gelişstirme (Yüksek lisans tezi, Gazi Üniversitesi, 2007), 22. 
sürecinde günlük hayatı kolaylaştırıcı unsurlar, ortak kültür alanları, ilgi çekici güncel durumlar ve uygulanabilir durumlar göz önünde bulundurulmalıdır. Bu hususların belirlenmesinden sonra uygun uygulama ortamları oluşturulmalı ve özellikle konuşmaya dayalı materyallerin tasarlanmasında kullanılmalıdır. ${ }^{17}$

Avrupa Dilleri Ortak Çerçeve Metnine göre dil öğretim kitaplarının hazırlanmasında çerçeve metinde yer alan seviyelere göre kültür ögelerinin seçimi önem arz etmektedir. $\mathrm{Bu}$ bağlamda Yabancı dil öğreten ders kitaplarında dört temel dil becerisine yönelik tasarlanmış materyallerde hangi kültür ögelerinin kullanılacağı ve bu ögelerin hangi sıra ve düzende verileceği önceden belirlenmelidir. Çerçeve metninde yer alan ilkelere uyumlu olarak Okur ve Keskin bu ögeleri 7 ana başlıkta toplamıştır: ${ }^{18}$

1. Günlük yaşam

2. Kişiler arası ilişskiler

3. Değerler ve eğitim

4. Edebiyat sanat ve müzik

5. Gelenekler ve folklor

6. Sosyal yaşam

7. Coğrafya ve mekân

Hedef dile ait kültür unsurları öğrenciye aktarılmadığı ve sadece dilin yapısının öğretildiği durumlarda öğrenci dili yetkin olarak kullanmakta zorluk çekecek ve öğrenilen yapıda sönme başlayacaktır. Çünkü kaynak kültürde yer alan bir davranış, yaşanabilir durum veya söz, hedef kültürde yer alan durumlarla bağdaşmayabilir ve öğrencinin dili uygulama yeterliği gerçekleşmeyebilir. Bu durum öğrencinin dile ilgisini azaltacak ve tam öğrenme gerçekleşmeyecektir. ${ }^{19}$

Kültür aktarımının sağlanması, her ne kadar hedef dilin öğretilmesinde etkin rol oynasa da bu aktarımı sağlamak için tek yönlü uygulamalar kullanmak, öğrenme sürecini olumsuz etkileyecektir. Bunun yerine kültürlerarası iletişim yoluyla hem öğrenciler arasında etkileşime olanak vermek, hem de hedef kültürle benzer ve ortak unsurları ön plana çıkarmak dilin etkin kullanımına ve tam öğrenmeye katkı sağlayacaktır. İltar, kültürlerarası iletişimsel yeterliği "Kültürlerarası iletişimsel yeterlik, bir arada yaşayan farklı kültür gruplarından insanların

17 İhsan Kalenderoğlu, «Türkçenin Yabancı Dil Olarak Öğretiminde Kullanılan Temel Düzey (A1, A2) Ders Kitaplarında Kültür Aktarımı», 21. Yüzyılda Eğitim Ve Toplum Eğitim Bilimleri Ve Sosyal Araștırmalar Dergisi 4/12 (2015), 76.

18 Okur ve Keskin, "Yabancılara Türkçe öğretiminde kültürel ögelerin aktarımı: İstanbul Yabancılar İçin Türkçe Öğretim Seti Örneği”, 1624.

19 Serdar Gürsoy ve İsmail Güleç, "Yabancılara Türkçe Öğretiminde Kültürel Ögelerin Aktarımı: Gökkuşağı Türkçe Öğretim Seti Temel Seviye Örneği”, IV. Sakarya'da Eğitim Araştırmaları Kongresi Bildiri Kitabı içinde (Sakarya: 2015), 102. 
etkileşim içerisinde bulunarak birbirlerinin kültürlerini karşılıklı olarak tanımaları ve etkili iletişim kurabilmeleridir" ${ }^{20}$ şeklinde tanımlamıştır.

Hedef dil ile kültür alışverişinde bulunmak, dili öğrenen için kolaylık sağlayacaktır. Kültürlerarası iletişim, en sık konuşma becerisine yönelik uygulama alanlarında karşımıza çıkmaktadır. Bu bağlamda kültürlerarası iletişimsel yaklaşımın hedefi olarak kültür alışverişi, konuşma becerişsini geliştirmek için çeşitli yöntemlerde kullanılmalıdır. Konuşma etkinliklerinde kültür alışverişine yer vermek öğrenenin dikkatini çekecek ve öğrenme kalıcı hâle gelecektir. Kültür unsurlarının da belirli bir düzen ve sırada bu yaklaşıma uygun şekilde materyallerde kullanılması gerekmektedir.

Bu bağlamda öğrenci yeterlikleri açısından kültürlerarası iletişimin yeri, Diller İçin Avrupa Ortak Öneriler Çerçevesi, Genel yeterlikler/Kültürlerarası Bilinç bölümünde şu şekilde ifade edilmiştir:

“Öneriler Çerçevesi’ni kullananlar, aşağıdaki noktayı dikkate alarak gereğinde:

- Dil öğrenenlerin hangi sosyokültürel deneyim ve bilgilerinin varsayilabileceğini ve onlara yöneltilen beklentileri;

- Dil öğrenenlerin D2'de sağlıklı bildirişim kurabilmeleri için hem kendi hem de hedef dil topluluğunda sosyal yaşamın yeni deneyimlerinin ve bilgilerinin hangilerini edinmek zorunda olduklarını;

- Dil öğrenenlerin uygun bir kültürlerarası yeterlik geliştirmeleri için kişinin kendi ve hedef kültürü arasında nasıl bir ilişki bilincine sahip olması gerektiğini belirtmelidirler." ${ }^{21}$

Türkçenin yabancı dil olarak öğretiminde öğrenicilerin kültürlerarası iletişimsel yeterliğini geliştirmek amacıyla öğrenicilerin kendi kültürlerine de yer vermek gerekmektedir. Öğrenicilerin kültürlerine değinmek öğrenicinin her iki kültür arasında kıyaslama yapmasına ve hedef kültürü daha iyi tanımasına olanak sağlar. ${ }^{22}$ Bu bağlamda yabancı dil olarak Türkçe ders kitaplarında yer alan konuşma etkinliklerinde kültür ögelerinin, iletişimsel yeterliğe olanak sağlayacak sorularla öğrenciye aktarımı sağlanmalıdır. Bu soruların sınıflardaki dil ve kültür çeşitliliği de hesaba katılarak oluşturulması ve gerektiğinde esnetilmesi önem arz etmektedir. Öğrenci kaynak kültür ile hedef kültür arasında ilişki kurarak öğrenme sürecine katılırsa, öğrencinin toplumdaki sosyal yaşantısı da iyileşecek ve dili günlük hayatta kullanmasına olanak sağlanacaktır.

\section{Araştırmanın Amacı}

Yabancılar için Türkçe ders kitaplarına bakıldı̆̆ında, konuşma becerisine yönelik etkinliklerinin sayısı ve dizilimi konusunda bir düzen olmadığı görülmektedir. Aynı şekilde

20 Latif İltar, "Kültürlerarası İletişimsel Dil Yeterliği Bağlamında Göçmenlere Türkçe Öğretimi”, Başar, Umut, Tüfekçioğlu Burak. (Ed.) Göçmelere Türkçe öğretimi içinde (Ankara: Nobel. 2020), 56.

21 Avrupa Konseyi/Modern Diller Bölümü, Diller İçin Avrupa Ortak Öneriler Çerçevesi Öğrenim, Öğretim ve Değerlendirme, 2013, 105.

22 Latif İltar, "Kültürlerarası İletişimsel Dil Yeterliği Bağlamında Göçmenlere Türkçe Öğretimi”, Başar, Umut, Tüfekçioğlu Burak. (Ed.) Göçmelere Türkçe öğretimi içinde (Ankara: Nobel. 2020), 64. 
konuşma etkinliklerinde yer alan kültürel ögelerin dağılımı konusunda da uygulama birliği olduğu söylenemez. Konuşma etkinliklerinin iletişimin en çok uygulandığı alan olduğu düşünüldüğünde, ders kitaplarının konuşma etkinliklerinde bu yaklaşıma dair uygulamaların bulunması ayrıca önem arz etmektedir. Bu bağlamda yabancılara Türkçe öğretiminde sıkça kullanılan İstanbul Yabancılar için Türkçe Öğretim Seti (İTÖS) ve Yedi İklim Türkçe Öğretim Seti (YİTÖS), konuşma etkinlikleri incelenerek "Konuşma etkinliklerinde kültürlerarası iletişimsel yaklaşıma dair uygulamalar ne sayıda kullanılmıştır ve bu uygulamalarda hangi kültür ögelerine yer verilmiştir?” sorusunun cevaplarını aramak ve bu cevapları yorumlamak amaçlanmıştır.

\section{Yöntem}

\subsection{Araştırmanın Modeli}

Araştırma nitel araştırma modellerinden durum çalışması ile ortaya konmuştur. Ders kitaplarındaki konuşmaya dayalı etkinlikler, kültürlerarası iletişimsel yaklaşım modeli ve kültür ögelerinin sıralanışına göre doküman incelemesi yöntemiyle incelenmiş, elde edilen veriler betimsel çözümlemenin sonucunda yorumlanmıştır.

\subsection{Evren ve Örneklem}

Yabancı dil olarak Türkçe ders kitaplarında yer alan konuşma etkinlikleri çalışmanın evreni olarak belirlenmiş, İstanbul Üniversitesi (İÜ) tarafından hazırlanmış İstanbul Yabancılar İçin Türkçe Öğretim Seti ve Yunus Emre Enstitüsü tarafından hazırlanmış Yedi İklim Türkçe Öğretim Seti'ne ait B1 ve B2 ders kitaplarındaki konuşma etkinlikleri ise örneklem olarak belirlenmiştir.

\subsection{Verilerin Toplanması ve Çözümlenmesi}

Araştırmada İstanbul Yabancılar İçin Türkçe Öğretim Seti ve Yedi İklim Türkçe Öğretim Seti 'nde yer alan konuşma etkinliklerinde yer alan kültürlerarası iletişime dair bulgular ve bulgulardaki kültür ögeleri, içerik analizi tekniğiyle ele alınmıştır. Verilerin sayıları ve yüzdelik değerleri sıralanmıştır.

Kültürlerarası iletişime dair bulgularda kültür ögelerinin tespiti için Okur ve Keskin'in çalışmasında kültür ögelerini belirledikleri tablodan yararlanılmıştır. ${ }^{23}$

23 Okur ve Keskin, "Yabancılara Türkçe öğretiminde kültürel ögelerin aktarımı: İstanbul Yabancılar İçin Türkçe Öğretim Seti Örneği”, 1624. 
Tablo 1. Metinlere Yansıyan Kültürel Öge ve Alt Ögeler ${ }^{24}$

\begin{tabular}{|c|c|c|c|c|c|c|c|}
\hline 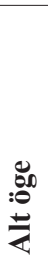 & 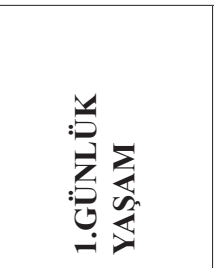 & 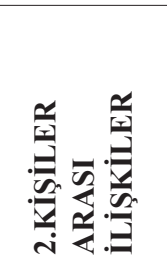 & 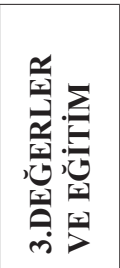 & 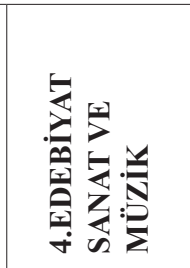 & 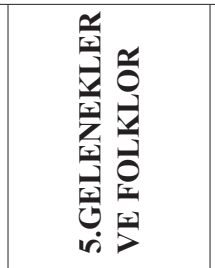 & 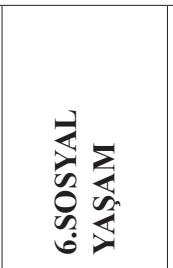 & 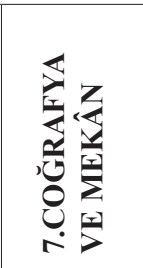 \\
\hline A & Yiyecek - içecek & Kişiler & Değerler & Edebiyat & $\begin{array}{l}\text { Özel günler ve } \\
\text { gelenekler }\end{array}$ & Moda & \multirow{9}{*}{$\begin{array}{c}\text { Yer(iller ve/ } \\
\text { veya diğer } \\
\text { yerleşim } \\
\text { yerleri) }\end{array}$} \\
\hline B & $\begin{array}{c}\text { Yemek zamanları, } \\
\text { sofra adabı }\end{array}$ & $\begin{array}{l}\text { Selamlaşma } \\
\text { ifade ve } \\
\text { davranışları }\end{array}$ & Eğitim & Müzik & $\begin{array}{c}\text { Sözlü anlatımlar } \\
\text { ve sözlü } \\
\text { gelenekler }\end{array}$ & Yasaklar & \\
\hline $\mathrm{C}$ & $\begin{array}{c}\text { Resmî tatiller- } \\
\text { çalışma zamanları }\end{array}$ & $\begin{array}{c}\text { Aile yapıları } \\
\text { ve ilişkileri, } \\
\text { kuşaklar arası } \\
\text { ilişkiler }\end{array}$ & $\begin{array}{c}\text { Dil ve } \\
\text { tarih } \\
\text { bilinci/ } \\
\text { sevgisi }\end{array}$ & Sanat & $\begin{array}{c}\text { Dini kurallara } \\
\text { dayalı davranışlar }\end{array}$ & $\begin{array}{c}\text { Alkış ve güzel } \\
\text { hareketler }\end{array}$ & \\
\hline $\mathrm{D}$ & $\begin{array}{c}\text { Boş zaman } \\
\text { etkinlikleri, } \\
\text { hobileri }\end{array}$ & $\begin{array}{c}\text { Politik ve } \\
\text { dinsel gruplar } \\
\text { arası ilişkiler }\end{array}$ & \multirow{6}{*}{ Diğerleri } & Gösteri sanatları & $\begin{array}{c}\text { Doğum, evlilik } \\
\text { gelenekleri }\end{array}$ & \multirow{6}{*}{ Diğerleri } & \\
\hline $\mathrm{E}$ & $\begin{array}{c}\text { Karş1lıklı } \\
\text { konuşmalarda } \\
\text { yaşa, cinsiyete, } \\
\text { yakınlık } \\
\text { derecesine, sosyal } \\
\text { statüye, resmiyete } \\
\text { göre kullanılacak } \\
\text { sözler ve kalıplar } \\
\end{array}$ & $\begin{array}{l}\text { Konuk etme- } \\
\text { ikram ve } \\
\text { hediyeler }\end{array}$ & & $\begin{array}{l}\text { El sanatları } \\
\text { geleneği }\end{array}$ & $\begin{array}{l}\text { Festivaller, } \\
\text { törenler, } \\
\text { kutlamalar }\end{array}$ & & \\
\hline $\mathrm{F}$ & $\begin{array}{l}\text { Yeme ve içme } \\
\text { alışkanlıkları }\end{array}$ & \multirow{4}{*}{ Diğerleri } & & \multirow{4}{*}{ Diğerleri } & Danslar & & \\
\hline G & Oyunlar & & & & $\begin{array}{c}\text { Toplumsal } \\
\text { uygulamalar, } \\
\text { ritüeller, bâtıl } \\
\text { inançlar }\end{array}$ & & \\
\hline $\mathrm{H}$ & Spor & & & & \begin{tabular}{|c|} 
Halk bilgisi, \\
evren ve doğa ile \\
ilgili uygulamalar
\end{tabular} & & \\
\hline$\dot{\mathrm{I}}$ & Müzik & & & & Diğerleri & & \\
\hline
\end{tabular}

\section{Bulgular}

\subsection{Konuşma Etkinliklerinde Kültürlerarası İletişimsel Yaklaşıma Ait Bulgular}

Çalı̧̧manın örneklemini teşkil eden dil öğretim setlerinden İTÖS ve YİTÖS (B1 ve B2) ders kitaplarına ait konuşma etkinlikleri incelenmiş, inceleme sonucunda kültürlerarası iletişimsel yaklaşıma uygunluğu tespit edilmiş olan konuşma etkinliklerinde bu yaklaşımın aktarılış

24 Okur ve Keskin, "Yabancılara Türkçe öğretiminde kültürel ögelerin aktarımı: İstanbul Yabanc1lar İçin Türkçe Öğretim Seti Örneği”, 1624. 
şekilleri ve kültür ögeleri tablolarda gösterilmiş, ayrıca kültürlerarası iletişimsel yaklaşıma uygun olan ve uygun olmayan konuşma etkinliklerine dair sayısal bilgiler belirtilmiştir. Konuşma etkinliklerinin tespitinde İTÖS ve YİTÖS ders kitaplarında hazırlık çalışmaları ve numaralandırılmamış ünite sonu serbest etkinlikler, çalışmanın standardını etkileyeceğinden çalışmaya dâhil edilmemiş, sadece İTÖS'te “Kültürden Kültüre” bölümleri kültürlerarası yaklaşımı destekleyeceği düşünüldüğünden çalışmaya dâhil edilmiştir. İTÖS'te bulunan "Konuşma" başlıklı etkinliklerin dışında "Ya Siz" bölümlerinin tamamı konuşma becerisini desteklediği için çalışmaya dâhil edilmiş, YİTÖS'te ise etkinliklerde bir beceri başlığı olmadığı için içeriğe göre seçim yapılmıştır.

\subsubsection{Konuşma Etkinliklerinde Kültürlerarasıı İletişimsel Yaklaşımın Aktarılış Şekillerine Ait Bulgular}

Çalışmaya konu olan İTÖS ve YİTÖS Türkçe öğretim setlerindeki konuşma etkinlikleri incelenmiş olup, kültürlerarası iletişimsel yaklaşıma uygun konuşma etkinliklerinde bu yaklaşımın aktarılış şekilleri ve kültür ögeleri tespit edilmiş ve tablolarda gösterilmiştir. Yapılan inceleme sonucunda İTÖS ve YİTÖS'te belirlenmiş konuşma etkinliklerinde, kültürlerarası yaklaşıma uygunluğu tespit edilmiş etkinliklerin kültürlerarası iletişimsel yaklaşımı aktarış şekilleri ve Okur ve Keskin'in (2013) çalışmasında yer alan kültür ögeleri tespit tablosundan yararlanılarak etkinliklerin kültür ögeleri başlıkları belirlenmiştir. Etkinliklerde kültürlerarası iletişimsel yaklaşıma dair aktarılış şekilleri, bu yaklaşıma uygun olan birer sorunun aynen aktarılmasıyla ortaya konmuştur. Bu yaklaşıma uygun 1'den fazla soru olması hâlinde en uygun olan seçilmiştir. Kültürel ögeler ise etkinliklerin tamamını kapsayan içeriğe göre belirlenmiştir.

\subsubsection{1. İTÖS B1 Düzeyi Konuşma Etkinliklerinde Kültürlerarası İletişimsel Yaklaşımın Aktarılış Şekillerine Ait Bulgular ve Yorumlar}

İOÖS B1 ders kitabında yer alan konuşma etkinliklerinde kültürlerarası iletişimsel yaklaşımın aktarılış şekilleri ve belirttiği kültür ögeleri şu şekildedir: 
Tablo 2. İTÖS B1 Konuşma Etkinliklerinde Kültürlerarası İletişimsel Yaklaşımın Aktarılış Şekillerine ve Kültür Ögelerine Ait Bulgular

\section{İstanbul Yabancılar Íçin Türkçe Öğretim Seti B1}

\begin{tabular}{|c|c|c|c|}
\hline Ünite Adı & Bölüm/Etkinlik/Sayfa & $\begin{array}{c}\text { Kültürlerarası İletişimsel } \\
\text { Yaklaşıma Ait Bulgu/Aktarılış } \\
\text { Şekli }\end{array}$ & $\begin{array}{c}\text { Kültürlerarası } \\
\text { İletişimsel Yaklaşıma } \\
\text { Ait Kültür Ögesi Türüi }\end{array}$ \\
\hline \multirow{7}{*}{$\begin{array}{l}\text { 1.Yeni Bir } \\
\text { Hayat }\end{array}$} & A-Ya Siz-9 & Yok & - \\
\hline & A-Konuşma-11 & Yok & _ \\
\hline & B-Ya Siz-13 & Yok & - \\
\hline & B-Konuşma-15 & Yok & - \\
\hline & C-Ya Siz-17 & Yok & - \\
\hline & C-Konuşma-19 & Yok & - \\
\hline & $\begin{array}{l}\text { Ünite Sonu-Kültürden } \\
\text { Kültüre-20 }\end{array}$ & $\begin{array}{l}\text { Türkçede, sizin dilinizdeki kelimelerle } \\
\text { aynı veya çok benzer şekilde söylenen } \\
\text { kelimeler var mı? }\end{array}$ & Değerler ve Eğitim \\
\hline \multirow{7}{*}{ 2.İş Dünyası } & A-Ya Siz-25 & Yok & - \\
\hline & A-Konuşma-27 & Yok & - \\
\hline & B-Ya Siz-30 & $\begin{array}{l}\text { Sizin ülkenizde de dünyaca ünlü başarılı } \\
\text { iş adamları var mı? Tanıtalım. }\end{array}$ & Değerler ve Eğitim \\
\hline & B-Konuşma-31 & Yok & - \\
\hline & C-Ya Siz-33 & Yok & - \\
\hline & C-Konuşma-35 & Yok & - \\
\hline & $\begin{array}{l}\text { Ünite Sonu-Kültürden } \\
\text { Kültüre-36 }\end{array}$ & $\begin{array}{l}\text { Sizin ülkenizde bunlar gibi ilginç } \\
\text { meslekler var mı? }\end{array}$ & Günlük Yaşam \\
\hline \multirow{6}{*}{$\begin{array}{l}\text { 3- Her Şeyin } \\
\text { Başı Sağlık }\end{array}$} & A-Ya Siz-41 & Yok & - \\
\hline & A-Konuşma-42 & Yok & - \\
\hline & B-Ya Siz-44 & Yok & - \\
\hline & B-Konuşma-47 & Yok & - \\
\hline & C-Ya Siz-49 & $\begin{array}{l}\text { Sizin kültürünüzde hangi taşların ne gibi } \\
\text { anlamları vardır? Niçin kullanılır? }\end{array}$ & Gelenekler ve Folklor \\
\hline & C-Konuşma-51 & Yok & _- \\
\hline
\end{tabular}




\begin{tabular}{|c|c|c|c|}
\hline \multirow{7}{*}{$\begin{array}{l}\text { 4- Eğitim } \\
\text { Hayatı }\end{array}$} & A-Ya Siz-58 & Yok & - \\
\hline & A-Konuşma-59 & Yok & - \\
\hline & B-Ya Siz-60 & Yok & - \\
\hline & B-Konuşma-62 & $\begin{array}{c}\text { Kendi dilimizle Türkçeyi karşılaştıralım. } \\
\text { Bu iki dil hangi yönleriyle farklı, hangi } \\
\text { yönleriyle benziyor? }\end{array}$ & Değerler ve Eğitim \\
\hline & C-Ya Siz-64 & Yok & - \\
\hline & C-Konuşma-65 & Yok & - \\
\hline & $\begin{array}{c}\text { Ünite Sonu-Kültürden } \\
\text { Kültüre-66 }\end{array}$ & Yok & - \\
\hline \multirow{7}{*}{$\begin{array}{l}\text { 5- } \\
\text { Hayallerimiz }\end{array}$} & A-Ya Siz-71 & Yok & - \\
\hline & A-Konuşma-73 & Yok & - \\
\hline & B-Ya Siz-75 & Yok & - \\
\hline & B-Konuşma-77 & Yok & - \\
\hline & C-Ya Siz-79 & Yok & - \\
\hline & C-Konuşma-81 & Yok & _ \\
\hline & $\begin{array}{l}\text { Ünite Sonu-Kültürden } \\
\text { Kültüre-82 }\end{array}$ & $\begin{array}{c}\text { Sizin ülkenizde herhangi bir sayının } \\
\text { uğuruna inanıyorlar mı? }\end{array}$ & Gelenekler ve Folklor \\
\hline \multirow{7}{*}{$\begin{array}{l}\text { 6- İnsanlar } \\
\text { Konuşa } \\
\text { Konuşa }\end{array}$} & A-Ya Siz-88 & Yok & - \\
\hline & A-Konuşma-89 & Yok & _ \\
\hline & B-Ya Siz-91 & Yok & - \\
\hline & B-Konuşma-93 & $\begin{array}{l}\text { Sizde aile toplantıları ne zaman olur? } \\
\text { Bu toplantılara kimler katı lır? En son } \\
\text { aile toplantınızı anlatınız. }\end{array}$ & Kişilerarası İlişkiler \\
\hline & C-Ya Siz-95 & $\begin{array}{l}\text { Memleketinizde yakın komşularınız var } \\
\text { mı? En çok hangisini seviyorsunuz? } \\
\text { Neden? }\end{array}$ & Kişilerarası İlişkiler \\
\hline & C-Konuşma-96 & $\begin{array}{l}\text { Ülkenizdeki komşuluk ilişkileri nasıl? } \\
\text { Anlatalım. }\end{array}$ & Kişilerarası İlişkiler \\
\hline & $\begin{array}{c}\text { Ünite Sonu-Kültürden } \\
\text { Kültüre-97 }\end{array}$ & $\begin{array}{l}\text { Sizin ülkenizde misafirler nasıl } \\
\text { ağırlanıyor? }\end{array}$ & Kişilerarası İlişkiler \\
\hline
\end{tabular}

Tablo incelendiğinde, İTÖS ders kitabında belirlenmiş olan konuşma etkinliklerinden 10’unda kültürlerarası yaklaşıma uygunluk tespit edilmiştir. Bu etkinliklerdeki kültür ögeleri, sistematik bir sıra içinde yer almamıştır. Kültürel iletişimsel yaklaşıma ait aktarılış şekilleri üstte de ifade edildiği gibi yaklaşıma uygun olan birer sorunun aynen aktarılmasıyla ortaya 
konmuş ve kültürel ögeler bu kapsamda belirlenmiştir. Kültürel İletişimsel Yaklaşıma uygun etkinliklerin ünitelere belli bir düzen ve sırada aktarılmadığı görülmektedir. Etkinliklerin 4'ünde "Kişilerarası İlişkiler” kültür ögesi tespit edilmiş, bu kültürel ögenin tamamı 6. Ünitede yer almıştır. Etkinliklerin 3'ünde “Değerler ve Eğitim” kültür ögesi tespit edilmiş, bu kültürel öge 1. Ünite, 2. Ünite ve 4. Ünitede yer almıştır. Etkinliklerin 2'sinde "Gelenekler ve Folklor" kültür ögesi tespit edilmiş, bu kültürel öge 3. ve 5. Ünitelerde yer almıştır. "Günlük Yaşam” kültür ögesi ise etkinliklerin 1'inde tespit edilmiş ve 2. Ünitede yer almıştır. Ayrıca kitapta yer alan 6 ünitenin 5'inde yer alan "Kültürden Kültüre" Ünite sonu etkinliklerinin 4'ünde kültürlerarası iletişimsel yaklaşıma uygunluk tespit edilmiştir. 3. Ünite "Kültürden Kültüre" etkinliğinde konuşma becerisine rastlanmamıştır.

\subsubsection{YİTÖS B1 Düzeyi Konuşma Etkinliklerinde Kültürlerarası İletişimsel Yaklaşımın Aktarılış Şekillerine Ait Bulgular ve Yorumlar}

YİTÖS B1 ders kitabında yer alan konuşma etkinliklerinde kültürlerarası iletişimsel yaklaşımın aktarılış şekilleri ve belirttiği kültür ögeleri şu şekildedir:

Tablo 3. YİTÖS B1 Konuşma Etkinliklerinde Kültürlerarası İletişimsel Yaklaşımın Aktarılış Şekillerine ve Kültür Ögelerine Ait Bulgular

\section{Yedi İklim Türkçe Öğretim Seti B1}

\begin{tabular}{|c|c|c|c|}
\hline Ünite Adı & Bölüm/Etkinlik/Sayfa & $\begin{array}{c}\text { Külttürlerarası İletişimsel Yaklaşım Ait } \\
\text { Bulgu/Aktarıış Şekli }\end{array}$ & $\begin{array}{c}\text { Kültürlerarası İletişimsel } \\
\text { Yaklaşıma Ait Külttür } \\
\text { Ögesi Türü }\end{array}$ \\
\hline \multirow{4}{*}{ 1.Haberin Var Mi?- } & A- $12-15$ & Yok & _ \\
\hline & B-7-19 & Yok & \\
\hline & C-4-22 & Yok & \\
\hline & C-6-23 & Yok & $=$ \\
\hline \multirow{5}{*}{$\begin{array}{l}\text { 2. Yorumlar ve } \\
\text { Görüşler }\end{array}$} & A-3-29 & Yok & \\
\hline & A-10-32 & Yok & $=$ \\
\hline & B-10-38 & Yok & \\
\hline & $\mathrm{C}-2-42$ & Yok & \\
\hline & C-4-43 & $\begin{array}{l}\text { Ülkenizdeki ünlü film yönetmenleri } \\
\text { kimlerdir? }\end{array}$ & Edebiyat, Sanat ve Müzik \\
\hline \multirow[b]{5}{*}{ 3.Eğitim } & A-11-56 & Yok & \\
\hline & B-8-60 & Sen hangi dilleri biliyorsun? & Kişilerarası İlişskiler \\
\hline & C-1-62 & Yok & \\
\hline & C-7-64 & Yok & \\
\hline & C-9-65 & Yok & \\
\hline
\end{tabular}




\begin{tabular}{|c|c|c|c|}
\hline \multirow{4}{*}{$\begin{array}{l}\text { 4. Gelin Tanış } \\
\text { Olalım }\end{array}$} & A-14-77 & Yok & \\
\hline & B-1-78 & Yok & \\
\hline & B-6-81 & Yok & - \\
\hline & C-10-87 & Yok & - \\
\hline \multirow[b]{3}{*}{$\begin{array}{l}\text { 5. Engelleri } \\
\text { Kaldıralım }\end{array}$} & A-9-97 & Yok & _ \\
\hline & B-5-100 & Yok & - \\
\hline & C-8-105 & Yok & - \\
\hline \multirow[b]{4}{*}{ 6. Kurgu } & A-3-112 & Yok & \\
\hline & B-6-121 & Yok & $=$ \\
\hline & B-7-121 & Yok & \\
\hline & $\mathrm{C}-2-124$ & $\begin{array}{l}\text { Ülkenizde/şehrinizde ne tür festivaller } \\
\text { yapılıyor? }\end{array}$ & Gelenekler ve Folklor \\
\hline \multirow{3}{*}{ 7. Kutlama } & A-11-135 & Yok & \\
\hline & B-7-141 & $\begin{array}{l}\text { Ülkenizde ve kültürünüzde bildiğiniz } \\
\text { olağanüstü olaylarla ilgili bir hikâye var } \\
\text { mı? Nedir? }\end{array}$ & Gelenekler ve Folklor \\
\hline & C-4-144 & $\begin{array}{c}\text { Sizce ülkeler arasında çeşitlilik gösteren } \\
\text { uygulamaların nedenleri nelerdir? }\end{array}$ & Gelenekler ve Folklor \\
\hline \multirow{4}{*}{ 8. Ömür Dediğin } & A-2-151 & $\begin{array}{l}\text { Siz de kültürünüze ait bir aşk hikâyesini } \\
\text { arkadaşlarınıza anlatınız. }\end{array}$ & Edebiyat, Sanat ve Müzik \\
\hline & A-5-152 & Yok & \\
\hline & B-3-157 & $\begin{array}{l}\text { Ülkenizde tarihe damgasını vuran } \\
\text { önemli şahsiyetlerden birini anlatınız. }\end{array}$ & Değerler ve Eğitim \\
\hline & C-2-162 & Yok & \\
\hline
\end{tabular}

Tablo incelendiğinde, YİTÖS ders kitabında belirlenmiş olan konuşma etkinliklerinden 7'sinde kültürlerarası yaklaşıma uygunluk tespit edilmiştir. Bu etkinliklerdeki kültür ögeleri, sistematik bir sıra içinde yer almamıştır. Kültürel iletişimsel yaklaşıma ait aktarılış şekilleri üstte de ifade edildiği gibi yaklaşıma uygun olan birer sorunun aynen aktarılmasıyla ortaya konmuş ve kültürel ögeler bu kapsamda belirlenmiştir. Kültürel İletişimsel Yaklaşıma uygun etkinliklerin ünitelere belli bir düzen ve sırada aktarılmadığı görülmektedir Etkinliklerin 3'ünde “Gelenekler ve Folklor” kültür ögesi tespit edilmiş, bu kültürel öge 6. ve 7. Ünitelerde yer almıştır. Ayrıca 7. Ünitede 2 farklı etkinlikte aynı kültürel ögeye yer verilmiştir. Etkinliklerin 2 'sinde "Edebiyat, Sanat ve Müzik" kültür ögesi tespit edilmiş, bu kültürel öge 2. Ünite ve 8 . Ünitede yer almıştır. Etkinliklerin 1'inde "Kişilerarası İlişkiler” kültür ögesi tespit edilmiş, bu öge 3. Ünitede yer almıştır. "Değerler ve Eğitim" kültür ögesi de etkinliklerin 1'inde tespit edilmiş ve 8. Ünitede yer almıştır.

\subsubsection{3. İTÖS B2 Düzeyi Konuşma Etkinliklerinde Kültürlerarası İletişimsel Yaklaşımın Aktarılış Şekillerine Ait Bulgular ve Yorumlar}

İTÖS B2 ders kitabında yer alan konuşma etkinliklerinde kültürlerarası iletişimsel yaklaşımın aktarılış şekilleri ve belirttiği kültür ögeleri şu şekildedir: 
Tablo 4. İTÖS B2 Konuşma Etkinliklerinde Kültürlerarası İletişimsel Yaklaşımın Aktarılış Şekillerine ve Kültür Ögelerine Ait Bulgular

İstanbul Yabancılar İçin Türkçe Öğretim Seti B2

\begin{tabular}{|c|c|c|c|}
\hline Ünite Adı & Bölüm/Etkinlik/Sayfa & $\begin{array}{c}\text { Kültürlerarası İletişimsel Yaklaşıma Ait } \\
\text { Bulgu/Aktarılış Şekli }\end{array}$ & $\begin{array}{c}\text { Kültürlerarası } \\
\text { İletişimsel Yaklaşıma Ait } \\
\text { Kültür Ögesi Türü }\end{array}$ \\
\hline \multirow{7}{*}{$\begin{array}{l}\text { 1.Leyleği } \\
\text { Havada } \\
\text { Görmek }\end{array}$} & A-Ya Siz-9 & Yok & - \\
\hline & A-Konuşma-11 & Yok & - \\
\hline & B-Ya Siz-13 & $\begin{array}{c}\text { Turistler sizin ülkenizde en çok hangi turizm } \\
\text { çeşidini tercih ediyor? Anlatalım. }\end{array}$ & Coğrafya ve Mekân \\
\hline & B-Konuşma-15 & Yok & - \\
\hline & C-Ya Siz-17 & $\begin{array}{l}\text { Sizin ülkenizde farklı dinlere ait kutsal yerler } \\
\text { var mı? Anlatalım. }\end{array}$ & Coğrafya ve Mekân \\
\hline & C-Konuşma-18 & Yok & - \\
\hline & $\begin{array}{l}\text { Ünite Sonu-Kültürden } \\
\text { Kültüre-19 }\end{array}$ & $\begin{array}{l}\text { Sizin kültürünüzde böyle kitaplar yazan } \\
\text { kişiler var mı? Bu kişiler ve kitaplar hakkında } \\
\text { kısaca bilgi verelim. }\end{array}$ & Edebiyat, Sanat ve Müzik \\
\hline \multirow{7}{*}{$\begin{array}{l}\text { 2.Geçmişten } \\
\text { Günümüze }\end{array}$} & A-Ya Siz-26 & Yok & - \\
\hline & A-Konuşma-28 & Yok & - \\
\hline & B-Ya Siz-31 & Yok & - \\
\hline & B-Konuşma-33 & Yok & - \\
\hline & C-Ya Siz-35 & Yok & - \\
\hline & C-Konuşma-38 & Yok & - \\
\hline & $\begin{array}{l}\text { Ünite Sonu-Kültürden } \\
\text { Kültüre-39 }\end{array}$ & Sizin ülkenizde oyuncak müzesi var mı? & Edebiyat, Sanat ve Müzik \\
\hline
\end{tabular}




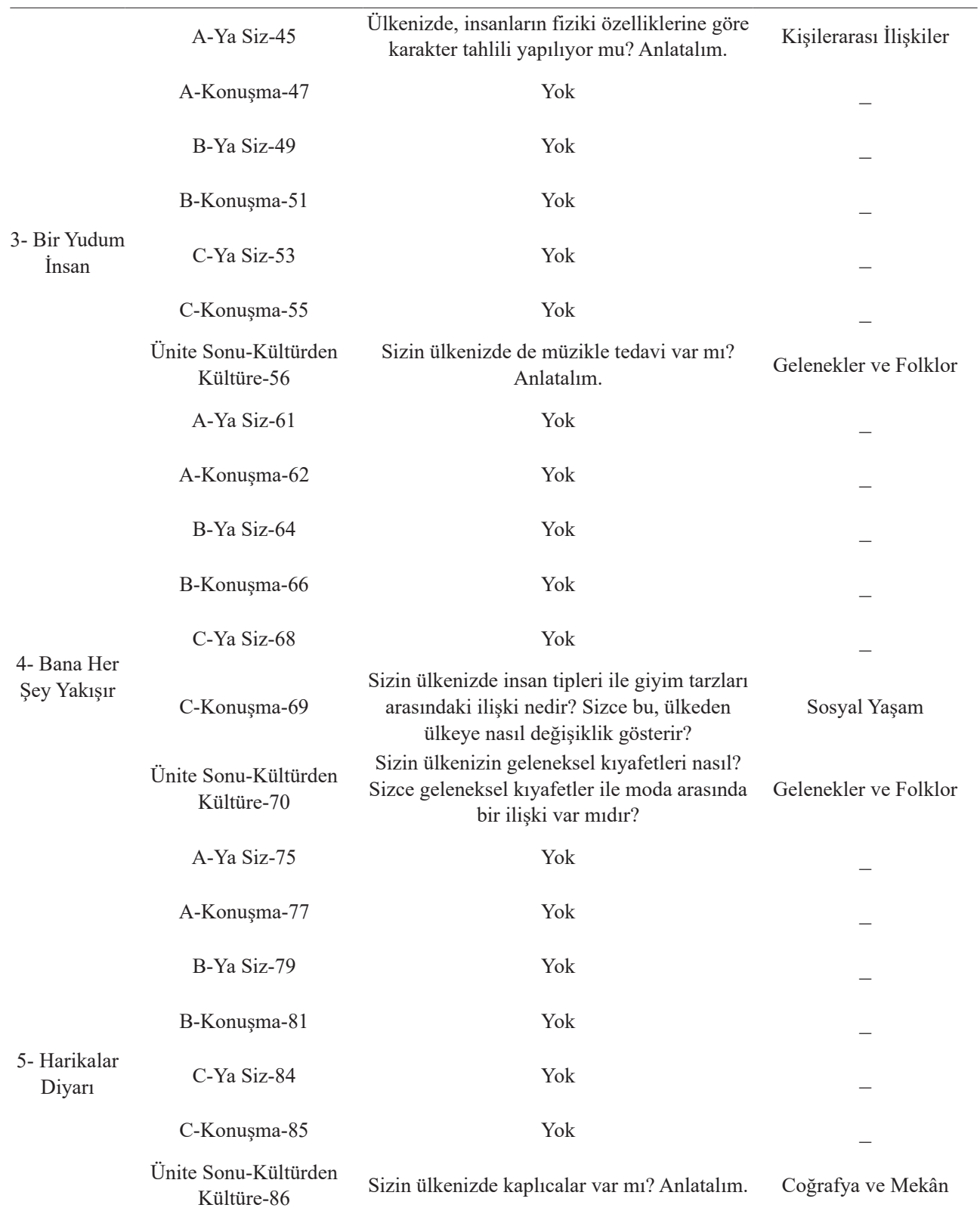




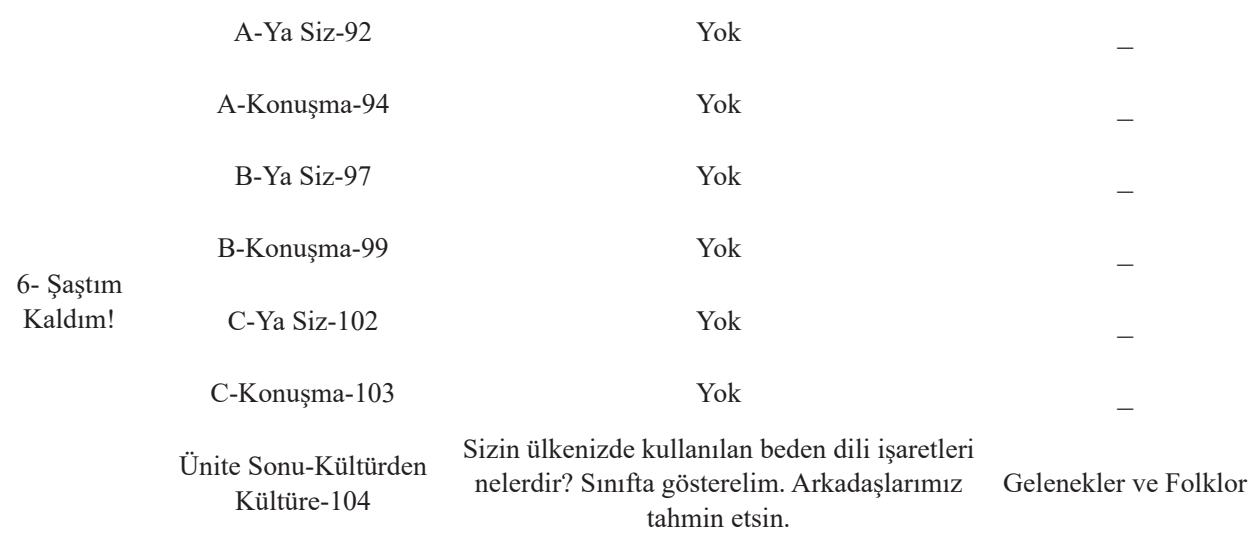

Tablo incelendiğinde, İTÖS ders kitabında belirlenmiş olan konuşma etkinliklerinden 10'unda kültürlerarası yaklaşıma uygunluk tespit edilmiştir. Bu etkinliklerdeki kültür ögeleri, sistematik bir sıra içinde yer almamıştır. Kültürel iletişimsel yaklaşıma ait aktarılış şekilleri üstte de ifade edildiği gibi yaklaşıma uygun olan birer sorunun aynen aktarılmasıyla ortaya konmuş ve kültürel ögeler bu kapsamda belirlenmiştir. Kültürel İletişimsel Yaklaşıma uygun etkinliklerin ünitelere belli bir düzen ve sırada aktarılmadığı görülmektedir. Etkinliklerin 3'ünde "Coğrafya ve Mekân” kültür ögesi tespit edilmiş, bu kültürel öge 1. ve 5. Ünitelerde yer almıştır. Ayrıca 1. Ünitede 2 farklı etkinlikte aynı kültürel ögeye yer verilmiştir. Etkinliklerin 3 'ünde "Gelenekler ve Folklor" kültür ögesi tespit edilmiş, bu kültürel öge 3. Ünite, 4. Ünite ve 6.Ünitede yer almıştır. Etkinliklerin 2'sinde “Edebiyat, Sanat ve Müzik” kültür ögesi tespit edilmiş, bu kültürel öge 1. ve 2. Ünitelerde yer almıştır. Etkinliklerin 1'inde "Kişilerarası İlişkiler” kültür ögesi tespit edilmiş, bu kültürel öge 3. Ünitede yer almıştır. "Sosyal Yaşam” kültür ögesi de etkinliklerin 1'inde tespit edilmiş ve 4. Ünitede yer almıştır. Ayrıca kitapta yer alan 6 ünitede de yer alan "Kültürden Kültüre" Ünite sonu etkinliklerinin hepsinde kültürlerarası iletişimsel yaklaşıma uygunluk tespit edilmiştir.

\subsubsection{YİTÖS B2 Düzeyi Konuşma Etkinliklerinde Kültürlerarası İletişimsel Yaklaşımın Aktarılış Şekillerine Ait Bulgular ve Yorumlar}

YİTÖS B2 ders kitabında yer alan konuşma etkinliklerinde kültürlerarası iletişimsel yaklaşımın aktarılış şekilleri ve belirttiği kültür ögeleri şu şekildedir: 
Tablo 5. YİTÖS B2 Konuşma Etkinliklerinde Kültürlerarası İletişimsel Yaklaşımın Aktarılış Şekillerine ve Kültür Ögelerine Ait Bulgular

\section{Yedi İklim Türkçe Öğretim Seti B2}

\begin{tabular}{|c|c|c|c|}
\hline Ünite Adı & Bölüm/Etkinlik/Sayfa & $\begin{array}{l}\text { Kültürlerarası İletişimsel Yaklaşım } \\
\text { Ait Bulgu/Aktarılış Şekli }\end{array}$ & $\begin{array}{c}\text { Kültürlerarası } \\
\text { İletişimsel Yaklaşıma } \\
\text { Ait Kültür Ögesi Türü }\end{array}$ \\
\hline \multirow[b]{4}{*}{$\begin{array}{l}\text { 1.Mesleğimde } \\
\text { İlerliyorum }\end{array}$} & A- $11-16$ & Yok & - \\
\hline & B-4-20 & Yok & - \\
\hline & B-10-22 & Yok & - \\
\hline & C-12-30 & $\begin{array}{l}\text { Dünya üniversiteleri arasındaki öğrenci } \\
\text { ve akademisyen değişimi programları } \\
\text { hakkında neler düşünüyorsunuz? Bu } \\
\text { programların ne tür yararları olabilir? }\end{array}$ & Değerler ve Eğitim \\
\hline \multirow{5}{*}{ 2.Değerlerimiz } & A-9-41 & $\begin{array}{c}\text { Sizin ülkenizdeki düğün gelenekleri } \\
\text { nelerdir? }\end{array}$ & Gelenekler ve Folklor \\
\hline & A-10-41 & $\begin{array}{l}\text { Bir ülke seçiniz. O ülkenin düğün } \\
\text { geleneğini canlandırınız. }\end{array}$ & Gelenekler ve Folklor \\
\hline & B-12-48 & Yok & - \\
\hline & $C-3-51$ & Yok & - \\
\hline & C-8-53 & $\begin{array}{l}\text { Kendi kültürünüzdeki komşuluk ile ilgili } \\
\text { sözlerden örnekler veriniz. }\end{array}$ & Kişilerarası İlişkiler \\
\hline \multirow{4}{*}{$\begin{array}{l}\text { 3- Bir Ömür Böyle } \\
\text { Geçti }\end{array}$} & A-11-63 & $\begin{array}{l}\text { Metindeki inanışlardan hangisi/hangileri } \\
\text { sizin kültürünüzde de vardır? }\end{array}$ & Gelenekler ve Folklor \\
\hline & B-2-4 & Yok & - \\
\hline & B-7-69 & Yok & - \\
\hline & C-9-77 & Yok & - \\
\hline \multirow{4}{*}{ 4- Mutfakta Kim Var? } & A-6-88 & Yok & - \\
\hline & B-7-91 & Yok & - \\
\hline & C-6-97 & Yok & - \\
\hline & C-7-97 & Yok & - \\
\hline \multirow[b]{3}{*}{ 5- Tercihiniz Nedir? } & A-7-106 & $\begin{array}{c}\text { Ülkenizin beğendiğiniz özellikleri } \\
\text { nelerdir? }\end{array}$ & Coğrafya ve Mekân \\
\hline & B-4-110 & $\begin{array}{l}\text { Sizin ülkenizde çalışma hayatında } \\
\text { kadınlar mı erkekler mi ön planda? } \\
\text { Niçin? }\end{array}$ & Kişilerarası İlişkiler \\
\hline & C-5-114 & $\begin{array}{l}\text { Sizin ülkenizde sanatçılar için söylenmiş } \\
\text { özlü bir söz var mı? Bu sözü Türkçe } \\
\text { söyleyin ve yazın. }\end{array}$ & $\begin{array}{l}\text { Edebiyat, Sanat ve } \\
\text { Müzik }\end{array}$ \\
\hline
\end{tabular}




\begin{tabular}{|c|c|c|c|}
\hline \multirow{3}{*}{$\begin{array}{l}\text { 6- Neler Oluyor } \\
\text { Hayatta? }\end{array}$} & A-10-125 & $\begin{array}{l}\text { Sizin de ailenizde ya da yakın } \\
\text { çevrenizde, doğadaki belirtilere bakarak } \\
\text { havanın nasıl olacağını bilenler var mı? }\end{array}$ & Gelenekler ve Folklor \\
\hline & B-6-132 & Yok & - \\
\hline & C-8-137 & Yok & - \\
\hline \multirow{4}{*}{$\begin{array}{l}\text { 7- Öğrendim, } \\
\text { Çalıştım, Başardım }\end{array}$} & A-6-146 & Yok & - \\
\hline & B-8-153 & Yok & - \\
\hline & C-2-154 & Yok & - \\
\hline & C-5-157 & Yok & - \\
\hline \multirow{4}{*}{$\begin{array}{l}\text { 8- Misafir Sever } \\
\text { misiniz? }\end{array}$} & A-8-167 & $\begin{array}{l}\text { Sizin ülkenizde misafirlerin karşılanması } \\
\text { ve uğurlanmasında neler söylenir? }\end{array}$ & Kişilerarası İliş̧kiler \\
\hline & B-6-172 & Yok & - \\
\hline & C-2-174 & Yok & - \\
\hline & C-8-177 & $\begin{array}{l}\text { Sizin köylerinizde misafirler nasıl } \\
\text { ağırlanır ve nerede kalırlar? }\end{array}$ & Kişilerarası İlişkiler \\
\hline
\end{tabular}

Tablo incelendiğinde, YİTÖS ders kitabında belirlenmiş olan konuşma etkinliklerinden 11 'inde kültürlerarası yaklaşıma uygunluk tespit edilmiştir. Bu etkinliklerdeki kültür ögeleri, sistematik bir sıra içinde yer almamıştır. Kültürel iletişimsel yaklaşıma ait aktarılış şekilleri üstte de ifade edildiği gibi yaklaşıma uygun olan birer sorunun aynen aktarılmasıyla ortaya konmuş ve kültürel ögeler bu kapsamda belirlenmiştir. Kültürel İletişimsel Yaklaşıma uygun etkinliklerin ünitelere belli bir düzen ve sırada aktarılmadığ 1 görülmektedir. Etkinliklerin 4'ünde “Gelenekler ve Folklor” kültür ögesi tespit edilmiş, bu kültürel öge 2.Ünite, 3. Ünite ve 6. Ünitelerde yer almıştır. Ayrıca 2. Ünitede 2 farklı etkinlikte aynı kültürel ögeye yer verilmiştir. Etkinliklerin yine 4'ünde "Kişilerarası İlişkiler" kültür ögesi tespit edilmiş, bu kültürel öge 2. Ünite, 5. Ünite ve 8.Ünitede yer almıştır. Ayrıca 8. Ünitede 2 farklı etkinlikte aynı kültürel ögeye yer verilmiştir. Etkinliklerin 1'inde “Değerler ve Eğitim”"kültür ögesi tespit edilmiş, bu kültürel öge 1. Ünitede yer almıştır. Etkinliklerin yine 1'inde "Coğrafya ve Mekân” kültür ögesi tespit edilmiş, bu kültürel öge 5. Ünitede yer almıştır. "Edebiyat, Sanat ve Müzik” kültür ögesi de etkinliklerin 1 'inde tespit edilmiş ve 5. Ünitede yer almıştır. Ayrıca 5. Ünitedeki konuşma etkinliklerinin tamamında kültürlerarası yaklaşıma ait uygunluk tespit edilmiştir.

\subsubsection{Konuşma Etkinliklerinde Kültürrlerarası İletişimsel Yaklaşıma Uygun Etkinlik Sayılarına İlişkin Bulgular}

Çalışmaya konu olan İTÖS ve YİTÖS Türkçe öğretim setlerindeki konuşma etkinlikleri incelenmiş olup, inceleme sonucunda kültürlerarası iletişimsel yaklaşıma uygunluğu tespit edilmiş olan konuşma etkinliklerinde kültürlerarası iletişimsel yaklaşıma uygun olan ve uygun 
olmayan konuşma etkinliklerine dair sayısal bilgiler tablo ve şekillerle gösterilmiştir. İTÖS ve YİTÖS'te yer alan ünite sayıları farklılık gösterdiği için sayıların karşılaştırılmasından ziyade oranların karşılaştırılması daha uygun olacaktır. Ayrıca İTÖS ders kitabında yer alan ünite sonu "Kültürden Kültüre” etkinlikleri, kültürlerarası iletişımsel yaklaşıma destek olacağı düşünüldüğünden çalışmaya ve oranlara dâhil edilmiştir.

\subsubsection{1. İTÖS B1 Düzeyi Konuşma Etkinliklerinde Kültürlerarası İletişimsel Yaklaşıma Uygun Etkinlik Sayılarına İlişsin Bulgular ve Yorumlar}

İTÖS B1 ders kitabında yer alan konuşma etkinliklerinde kültürlerarası iletişimsel yaklaşıma uygun olan ve uygun olmayan konuşma etkinliklerine dair sayısal ve oransal bilgiler aşağıda belirtilmiştir.

Tablo 6. İTÖS B1 Konuşma Etkinliklerinde Kültürlerarası İletişimsel Yaklaşıma Uygun Etkinlik Sayıları

\begin{tabular}{cccc}
\hline & \multicolumn{2}{c}{ İstanbul Yabancılar İçin Türkçe Öğretim Seti B1 } \\
\hline Ünite Adı & $\begin{array}{c}\text { Külttürlerarası İletişimsel } \\
\text { Yaklaşıma Uygun Konuşma } \\
\text { Etkinliği Sayısı }\end{array}$ & $\begin{array}{c}\text { Kültürrlerarası İletişimsel } \\
\text { Yaklaşıma Uygun Olmayan } \\
\text { Konuşma Etkinliği Sayısı }\end{array}$ & $\begin{array}{c}\text { Toplam Konuşma } \\
\text { Etkinliği Sayısı }\end{array}$ \\
\hline 1.Yeni Bir Hayat & 1 & 6 & 7 \\
\hline 2.İs Dünyası & 2 & 5 & 7 \\
\hline $\begin{array}{c}\text { 3- Her Şeyin Başı } \\
\text { Sağlık }\end{array}$ & 1 & 5 & 7 \\
\hline 4- Eğitim Hayatı & 1 & 6 & 7 \\
\hline 5- Hayallerimiz & 1 & 3 & 7 \\
\hline 6- İnsanlar Konuşa & 4 & 31 & 41 \\
\hline Konuşa & 10 & & 6 \\
\hline Toplam & & 6 & 7 \\
\hline
\end{tabular}

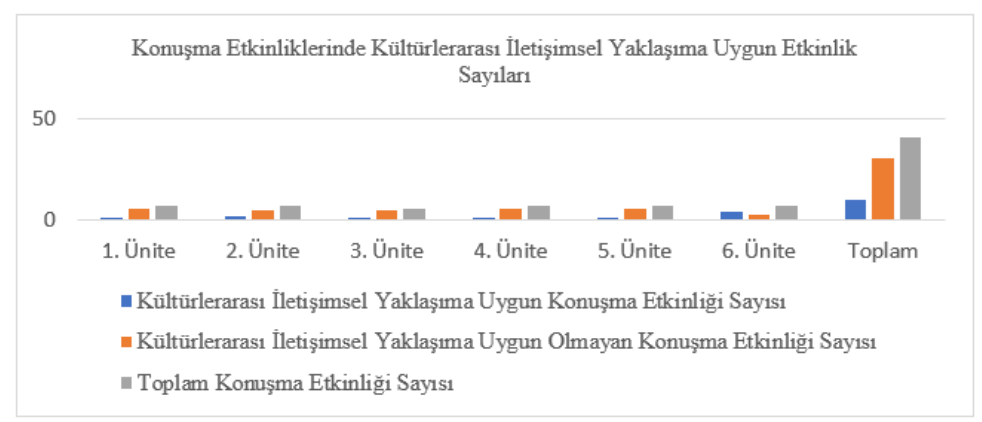

Şekil 1: İTÖS B1 Konuşma Etkinliklerinde Kültürlerarası İletişimsel Yaklaşıma Uygun Etkinlik Sayıları 


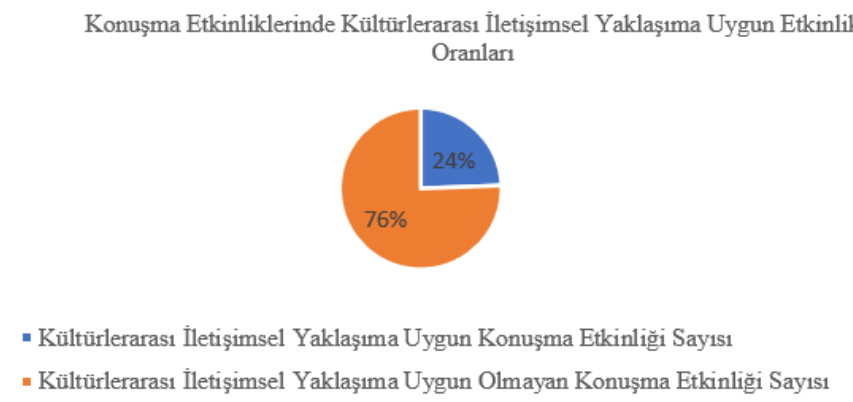

Şekil 2: İTÖS B1 Konuşma Etkinliklerinde Kültürlerarası İletişimsel Yaklaşıma Uygun Etkinliklerin Oranı

Tablo ve şekiller incelendiğinde İTÖS B1 ders kitabında belirlenmiş olan 41 konuşma etkinliğinden 10'unda kültürlerarası yaklaşıma uygunluk tespit edilmiş, 31'inde uygunluk tespit edilmemiştir. Konuşma etkinlikleri incelendiğinde 1.Ünitede 7 etkinlikten 1'i, 2.Ünitede 7 etkinlikten 2'si, 3. Ünitede 6 etkinlikten 1'i, 4. Ünitede 7 etkinlikten 1'i, 5. Ünitede 7 etkinlikten 1'i, 6. Ünitede ise 7 etkinlikten 4'ü kültürlerarası iletişimsel yaklaşıma uygun olarak belirlenmiştir. Kültürlerarası iletişimsel yaklaşıma uygun etkinliklerin ünitelere sistematik bir düzende aktarılmadığı görülmüştür. 6. Ünitede yaklaşıma uygun 4 etkinliğin olması bunun göstergesidir. Yüzdelik değerlere göre bakıldığında ise kitabın tamamında yer alan konuşma etkinliklerinde kültürlerarası iletişime uygun etkinliklerin oranının \%24 olduğu görülmektedir. $\mathrm{Bu}$ oran üniteler özelinde değerlendirildiğinde farklılık arz edecektir. İTÖS ders kitabının 6 ünite olması oransal verileri YİTÖS ile karşılaştırma açısından etkilememiştir.

\subsubsection{YİTÖS B1 Düzeyi Konuşma Etkinliklerinde Kültürlerarası İletişimsel Yaklaşıma Uygun Etkinlik Sayılarına İlişsin Bulgular ve Yorumlar}

YİTÖS B1 ders kitabında yer alan konuşma etkinliklerinde kültürlerarası iletişimsel yaklaşıma uygun olan ve uygun olmayan konuşma etkinliklerine dair sayısal ve oransal bilgiler aşağıda belirtilmiş̧ir. 
Tablo 7. YİTÖS B1 Konuşma Etkinliklerinde Kültürlerarası İletişimsel Yaklaşıma Uygun Etkinlik Sayıları

\begin{tabular}{cccc}
\hline & \multicolumn{1}{c}{ Yedi İklim Türkçe Öğretim Seti B1 } & \\
\hline Ünite Adı & $\begin{array}{c}\text { Kültürlerarası İletişimsel } \\
\text { Yaklaşıma Uygun Konuşma } \\
\text { Etkinliği Sayısı }\end{array}$ & $\begin{array}{c}\text { Kültürlerarası İletişimsel } \\
\text { Yaklaşıma Uygun Olmayan } \\
\text { Konuşma Etkinliği Sayısı }\end{array}$ & $\begin{array}{c}\text { Toplam Konuşma } \\
\text { Etkinliği Sayısı }\end{array}$ \\
\hline $\begin{array}{c}\text { 1.Haberin Var Mı? } \\
\text { 2. Yorumlar ve } \\
\text { Görüşler }\end{array}$ & 0 & 4 & 4 \\
\hline $\begin{array}{c}\text { 3.Eğgitim } \\
\text { 4. Gelin Tanış }\end{array}$ & 1 & 4 & 5 \\
\hline $\begin{array}{l}\text { Olalım } \\
\text { Kaldıralım }\end{array}$ & 1 & 4 & 4 \\
\hline 6. Kurgu & 0 & 4 & 3 \\
\hline 7. Kutlama & 0 & 3 & 4 \\
\hline 8. Ömür Dediğin & 1 & 3 & 3 \\
\hline Toplam & 2 & 1 & 4 \\
\hline
\end{tabular}

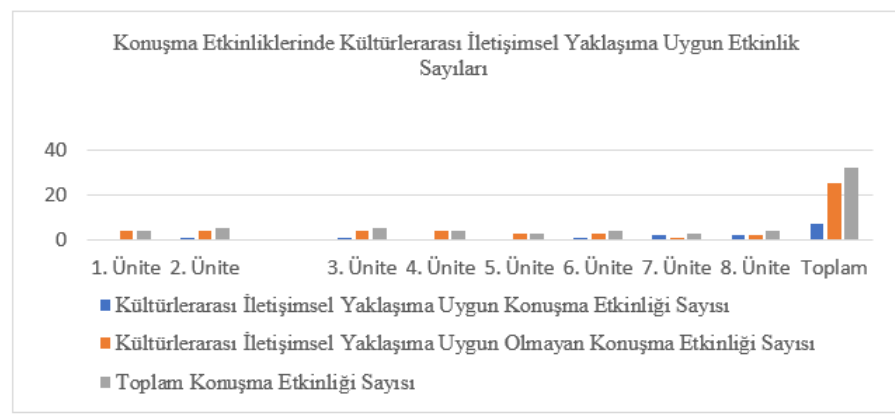

Şekil 3: YİTÖS B1 Konuşma Etkinliklerinde Kültürlerarası İletişimsel Yaklaşıma Uygun Etkinlik Sayıları

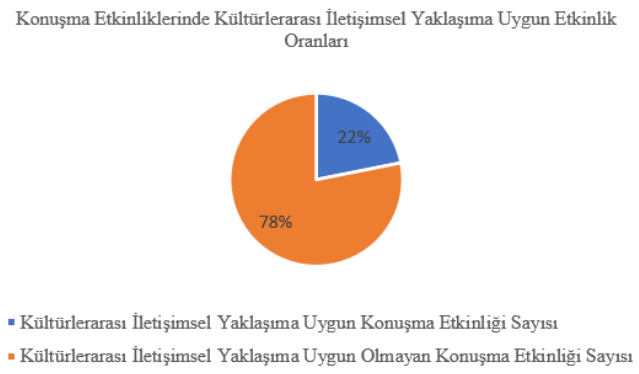

- Kültürlerarası İletişimsel Yaklaşıma Uygun Konuşma Etkinliği Sayısı

- Kültürlerarası İletişimsel Yaklaşıma Uygun Olmayan Konuşma Etkinliği Sayısı

Şekil 4: YİTÖS B1 Konuşma Etkinliklerinde Kültürlerarası İletişimsel Yaklaşıma Uygun Etkinliklerin Oranı 
Tablo ve şekiller incelendiğinde YİTÖS B1 ders kitabında belirlenmiş olan 32 konuşma etkinliğinden 7'sinde kültürlerarası yaklaşıma uygunluk tespit edilmiş, 25'inde uygunluk tespit edilmemiştir. Konuşma etkinlikleri incelendiğinde 1.Ünite, 4. Ünite ve 5. Ünitelerde kültürlerarası iletişimsel yaklaşıma uygun etkinlik tespit edilememiş, 2.Ünitede 5 etkinlikten 1'i, 3. Ünitede 5 etkinlikten 1'i, 6. Ünitede 4 etkinlikten 1'i, 7. Ünitede 3 etkinlikten 2'si, 8. Ünitede ise 4 etkinlikten 2'si kültürlerarası iletişimsel yaklaşıma uygun olarak belirlenmiştir. Kültürlerarası iletişimsel yaklaşıma uygun etkinliklerin ünitelere sistematik bir düzende aktarılmadığı görülmüştür. 7. Ünitede 3 etkinlikten yaklaşıma uygun 2 etkinliğin olması bunun göstergesidir. Yüzdelik değerlere göre bakıldığında ise kitabın tamamında yer alan konuşma etkinliklerinde kültürlerarası iletişime uygun etkinliklerin oranının \%22 olduğu görülmektedir. Bu oran üniteler özelinde değerlendirildiğinde farklılık arz edecektir. YİTÖS ders kitabının 8 ünite olması oransal verileri İTÖS ile karşılaştırma açısından etkilememiştir.

\subsubsection{3. İTÖS B2 Düzeyi Konuşma Etkinliklerinde Kültürlerarası İletişimsel Yaklaşıma Uygun Etkinlik Sayılarına İlişkin Bulgular}

İTÖS B2 ders kitabında yer alan konuşma etkinliklerinde kültürlerarası iletişimsel yaklaşıma uygun olan ve uygun olmayan konuşma etkinliklerine dair sayısal ve oransal bilgiler aşağıda belirtilmiştir.

Tablo 8: İTÖS B2 Konuşma Etkinliklerinde Kültürlerarası İletişimsel Yaklaşıma Uygun Etkinlik Sayılar1

\begin{tabular}{cccc}
\hline \multicolumn{4}{c}{ İstanbul Yabancılar İçin Türkçe Öğretim Seti B2 } \\
\hline Ünite Adı & $\begin{array}{c}\text { Kültürlerarası İletişimsel } \\
\text { Yaklaşıma Uygun Konuşma } \\
\text { Etkinliği Sayısı }\end{array}$ & $\begin{array}{c}\text { Kültürlerarası İletişimsel } \\
\text { Yaklaşıma Uygun Olmayan } \\
\text { Konuşma Etkinliği Sayısı }\end{array}$ & $\begin{array}{c}\text { Toplam Konuşma } \\
\text { Etkinliği Sayısı }\end{array}$ \\
\hline $\begin{array}{c}\text { 1.Leyleği Havada } \\
\text { Görmek }\end{array}$ & 3 & 4 & 7 \\
\hline $\begin{array}{c}\text { 2.Geçmişten } \\
\text { Günümüze }\end{array}$ & 1 & 6 & 7 \\
\hline 3- Bir Yudum İnsan & 2 & 5 & 7 \\
\hline $\begin{array}{c}\text { 4- Bana Her Şey } \\
\text { Yakışır }\end{array}$ & 2 & 5 & 7 \\
\hline 5- Harikalar Diyarı & 1 & 6 & 7 \\
\hline 6- Şaştım Kaldım! & 1 & 6 & 42 \\
\hline Toplam & 10 & 32 & 7 \\
\hline
\end{tabular}




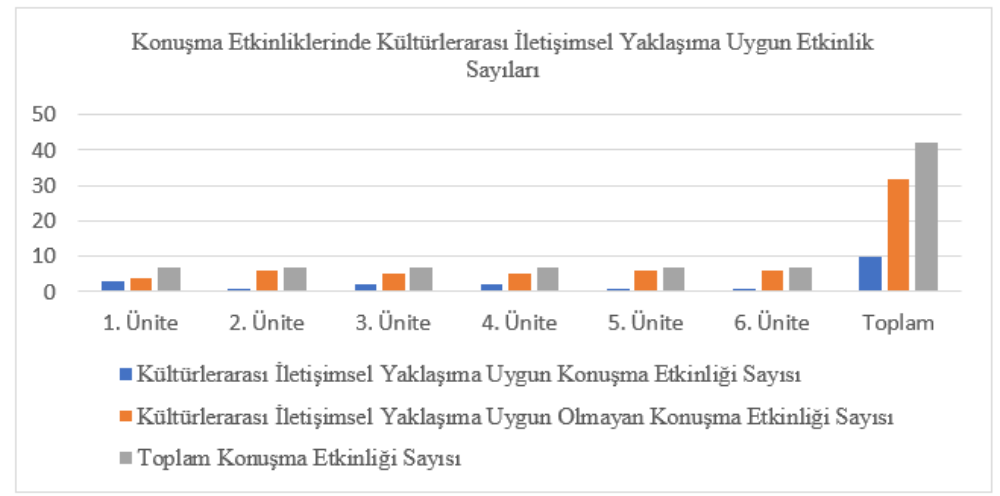

Şekil 5: İTÖS B2 Konuşma Etkinliklerinde Kültürlerarası İletişimsel Yaklaşıma Uygun Etkinlik Sayıları

İTÖS B2 Konuşma Etkinliklerinde Kültürlerarası İletişimsel Yaklaşıma Uygun Etkinlik Sayıları

- Kültürlerarası İletişimsel Yaklaşıma Uygun Konuşma Etkinliği Sayısı

- Kültürlerarası İletişimsel Yaklaşıma Uygun Olmayan Konuşma Etkinliği Sayısı

Şekil 6: İTÖS B2 Konuşma Etkinliklerinde Kültürlerarası İletişimsel Yaklaşıma Uygun Etkinliklerin Oranı

Tablo ve şekiller incelendiğinde İTÖS B2 ders kitabında belirlenmiş olan 42 konuşma etkinliğinden 10'unda kültürlerarası yaklaşıma uygunluk tespit edilmiş, 32'sinde uygunluk tespit edilmemiştir. Konuşma etkinlikleri incelendiğinde 1.Ünitede 7 etkinlikten 3'ü, 2.Ünitede 7 etkinlikten 1 'i, 3. Ünitede 7 etkinlikten 2'si, 4. Ünitede 7 etkinlikten 2'si, 5. Ünitede 7 etkinlikten 1 'i, 6 . Ünitede ise 7 etkinlikten 1 'i kültürlerarası iletişimsel yaklaşıma uygun olarak belirlenmiştir. Kültürlerarası iletişimsel yaklaşıma uygun etkinliklerin ünitelere sistematik bir düzende aktarılmadığı görülmüştür. 1. Ünitede yaklaşıma uygun 3 etkinliğin olması bunun göstergesidir. Yüzdelik değerlere göre bakıldığında ise kitabın tamamında yer alan konuşma etkinliklerinde kültürlerarası iletişime uygun etkinliklerin oranının \%24 olduğu görülmektedir. $\mathrm{Bu}$ oran üniteler özelinde değerlendirildiğinde farklılık arz edecektir. İTÖS ders kitabının 6 ünite olması oransal verileri YİTÖS ile karşılaştırma açısından etkilememiştir. 


\subsubsection{YİTÖS B2 Düzeyi Konuşma Etkinliklerinde Kültürlerarası İletişimsel Yaklaşıma Uygun Etkinlik Sayılarına İlişkin Bulgular}

YİTÖS B2 ders kitabında yer alan konuşma etkinliklerinde kültürlerarası iletişimsel yaklaşıma uygun olan ve uygun olmayan konuşma etkinliklerine dair sayısal ve oransal bilgiler aşağıda belirtilmiştir.

Tablo 9. YİTÖS B2 Konuşma Etkinliklerinde Kültürlerarası İletişimsel Yaklaşıma Uygun Etkinlik Say1ları

\begin{tabular}{cccc}
\hline & \multicolumn{2}{c}{ Yedi İklim Türkçe Öğretim Seti B2 } & \\
\hline Ünite Adı & $\begin{array}{c}\text { Kültürlerarası İletişimsel } \\
\text { Yaklaşıma Uygun Konuşma } \\
\text { Etkinliği Sayısı }\end{array}$ & $\begin{array}{c}\text { Kültürlerarası İletişimsel } \\
\text { Yaklaşıma Uygun Olmayan } \\
\text { Konuşma Etkinliği Sayısı }\end{array}$ & $\begin{array}{c}\text { Toplam Konuşma } \\
\text { Etkinliği Sayısı }\end{array}$ \\
\hline $\begin{array}{c}\text { 1.Mesleğimde } \\
\text { İlerliyorum }\end{array}$ & 1 & 3 & 4 \\
\hline 2.Değerlerimiz & 3 & 2 & 5 \\
\hline 3- Bir Ömür Böyle Geçti & 1 & 3 & 4 \\
\hline 4- Mutfakta Kim Var? & 0 & 4 & 3 \\
\hline 5- Tercihiniz Nedir? & 3 & 0 & 3 \\
\hline $\begin{array}{c}\text { 6- Neler Oluyor } \\
\text { Hayatta? }\end{array}$ & 1 & 2 & 4 \\
\hline $\begin{array}{c}\text { 7- Öğrendim, Çalıştım, } \\
\text { Başardım }\end{array}$ & 0 & 4 & 4 \\
\hline $\begin{array}{c}\text { 8- Misafir Sever } \\
\text { misiniz? }\end{array}$ & 2 & 2 & 31 \\
\hline \begin{tabular}{c} 
Toplam \\
\hline
\end{tabular} & 11 & 20 & 3 \\
\hline
\end{tabular}

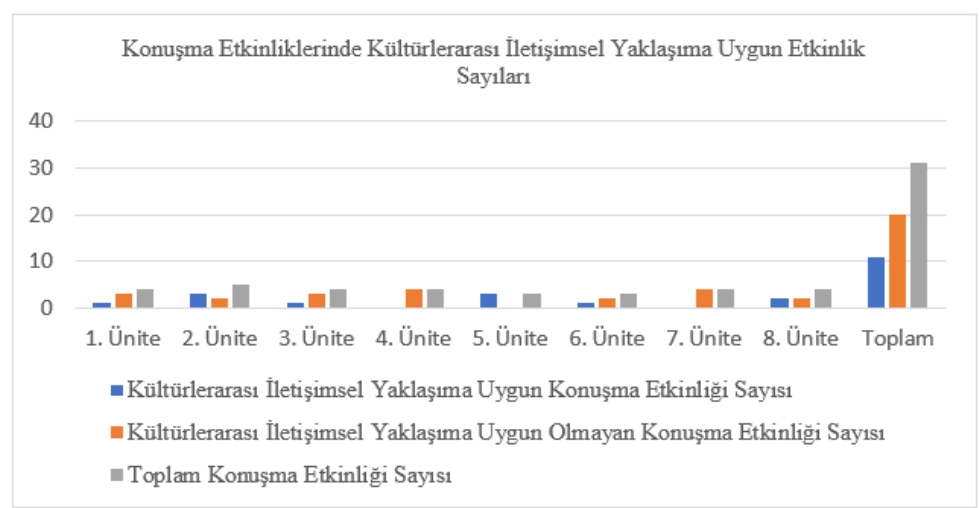

Şekil 7: YİTÖS B2 Konuşma Etkinliklerinde Kültürlerarası İletişimsel Yaklaşıma Uygun

Etkinlik Sayıları 
Konuşma Etkinliklerinde Kültürlerarası İletişimsel Yaklaşıma Uygun Etkinlik Sayları

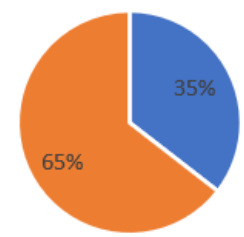

- Kültürlerarası İletişimsel Yaklaşıma Uygun Konuşma Etkinliği Sayısı

- Kültürlerarası İletişimsel Yaklaşıma Uygun Olmayan Konuşma Etkinliği Sayısı

Şekil 8: YİTÖS B2 Konuşma Etkinliklerinde Kültürlerarası İletişimsel Yaklaşıma Uygun Etkinliklerin Oranı

Tablo ve şekiller incelendiğinde YİTÖS B2 ders kitabında belirlenmiş olan 31 konuşma etkinliğinden 11 'inde kültürlerarası yaklaşıma uygunluk tespit edilmiş, 20'sinde uygunluk tespit edilmemiştir. Konuşma etkinlikleri incelendiğinde 4. Ünite ve 7. Ünitelerde kültürlerarası iletişimsel yaklaşıma uygun etkinlik tespit edilememiş, 1.Ünitede 4 etkinlikten 1'i, 2. Ünitede 5 etkinlikten 3 'ü, 3. Ünitede 4 etkinlikten 1 'i, 5 . Ünitede 3 etkinlikten 3'ü, 6 . Ünitede 3 etkinlikten 1'i, 8. Ünitede 4 etkinlikten 2'si kültürlerarası iletişimsel yaklaşıma uygun olarak belirlenmiştir. Kültürlerarası iletişimsel yaklaşıma uygun etkinliklerin ünitelere sistematik bir düzende aktarılmadığı görülmüştür. 3. Ünitede 3 konuşma etkinliğinin tamamının yaklaşıma uygun olması bunun göstergesidir. Yüzdelik değerlere göre bakıldığında ise kitabın tamamında yer alan konuşma etkinliklerinde kültürlerarası iletişime uygun etkinliklerin oranının \% 035 olduğu görülmektedir. Bu oran üniteler özelinde değerlendirildiğinde farklılık arz edecektir. YİTÖS ders kitabının 8 ünite olması oransal verileri İTÖS ile karşılaştırma açısından etkilememiştir.

\section{Sonuç ve Öneriler}

Bu çalışmada örneklemi oluşturan İTÖS ve YİTÖS (B1, B2) ders kitaplarındaki konuşma etkinlikleri, kültürlerarası iletişimsel yaklaşım modeline uygunluk bakımından incelenip çözümlenmiş, bu etkinliklerde kültürlerarası iletişimsel yaklaşıma uygunluk, yaklaşımın aktarılış şekilleri ve içerisinde barındırdıkları kültür ögeleri tespit edilmiştir.

Konuşma etkinliklerini tespit ederken İTÖS ve YİTÖS ders kitaplarındaki hazırlık çalışmaları ve ünite sonu serbest etkinlikler, beceri temelli bir düzende olmadıkları için çalışmaya dâhil edilmemiştir. Sadece İTÖS ders kitaplarında yer alan "Kültürden Kültüre” bölümleri, araştırmanın temelini destekleyeceği düşünüldüğünden çalışmaya dâhil edilmiştir. Ayrıca, İTÖS ders kitabı için "Konuşma" başlıklı etkinlikler ve "Ya Siz" başlıklı etkinliklerin tamamı konuşma becerisini temel aldığı için çalışmaya dâhil edilmiştir. YİTÖS ders kitabı için ise numaralandırılmış etkinliklerde, 
konuşma becerisine yönelik etkinliklerin tamamı ele alınmıştır. Bu bağlamda iki ders kitabı arasında konuşma becerisine yönelik etkinliklerde düzen veya sıralamaya göre bir benzerlik veya uygulama birliğine rastlanılmamıştır. İTÖS ders kitaplarında konuşma etkinliklerinin "Konuşma" başlı̆̆ altında verilmesi, "Ya Siz" başlığı altındaki etkinliklerin tamamında konuşma becerisine yönelik uygulamaların olması, ayrıca "Kültürden Kültüre" bölümlerinin tamamına yakınında konuşma becerisine yönelik uygulamaların olması, İTÖS ders kitabının kendi içinde bir düzen ve sıralamaya sahip olduğunu göstermektedir. Fakat etkinlik başlıklarının yerine etkinlik içindeki her soruya farklı numara verilmesi, tablolarda etkinliklerin numaralarıyla değil isimleriyle yazma zorunluluğu doğurmuştur. YİTÖS ders kitabında ise her etkinlik başlığının farklı numarayla belirtilmesi, tabloda etkinliklerin belirtilmesinde kolaylık sağlamıştır. YITÖO ders kitaplarında konuşma becerisine yönelik etkinlikler ayrı bir başlık veya düzenli bir sıralamayla numaralandırılmamıştır. Yani konuşma etkinliklerinde sistematik bir düzen yoktur.

İTÖS ve YİTÖS ders kitaplarında yer alan konuşma etkinliklerinde kültürlerarası iletişime uygun etkinlikler belirlendikten sonra Keskin'in (2013) çalışmasında yer alan kültür ögeleri tespit tablosundan yararlanılarak etkinliklerin kültür ögeleri başlıkları belirlenmiştir. Kültürlerarası iletişime uygunluğun tespitinden sonra bu yaklaşımın etkinliklerde ne şekilde aktarıldığı belirlenmiştir.

İTÖS B1 ders kitabında belirlenmiş olan konuşma etkinlikleri çözümlenmiş ve etkinliklerin 10'unda kültürlerarası yaklaşıma uygun içerik tespit edilmiştir. Konuşma etkinlikleri incelendiğinde 4 farklı kültür ögesine rastlanılmış, etkinliklerde 4 tane "Kişilerarası İlişkiler" kültür ögesi tespit edilmiş, bu kültür ögesinin tamamı 6. Ünitede yer almıştır. Bu ögelerin aynı ünitede yer almış olmasının nedeni ünite konusunun bu ögenin içeriğini kapsaması olarak gösterilebilir. Etkinliklerde 3 tane "Değerler ve Eğitim" kültür ögesi, 2 tane "Gelenekler ve Folklor" kültür ögesi ve 1 tane "Günlük Yaşam" kültür ögesi tespit edilmiştir. Bu yaklaşıma göre tespit edilen etkinliklerdeki kültür ögelerinin dağılımı, belli bir düzen veya sıraya göre yapılmamıştır. Ders kitabında yer alan yaklaşıma uygun belirlediğimiz konuşma etkinliklerinde "Edebiyat, Sanat ve Müzik", "Sosyal Yaşam" ve "Coğrafya ve Mekân” üst kültür ögelerine rastlanılmamıştır. Ders kitabında yer alan 6 ünitenin 5 'inde yer alan "Kültürden Kültüre" ünite sonu etkinliklerinin 4'ünde kültürlerarası iletişimsel yaklaşıma uygunluk tespit edilmiştir. $\mathrm{Bu}$ bağlamda "Kültürden Kültüre" etkinliklerinde çoğunlukla kültürlerarası iletişimsel yaklaşıma ait bulguların olması, bu etkinliklerin amaca uygun şekilde tasarlandığını göstermektedir.

YİTÖS B1 ders kitabında belirlenmiş olan konuşma etkinlikleri çözümlenmiş ve etkinliklerin 7 'sinde kültürlerarası yaklaşıma uygun içerik tespit edilmişstir. Konuşma etkinlikleri incelendiğinde 4 farklı kültür ögesine rastlanılmış, etkinliklerde 3 tane "Gelenekler ve Folklor" kültür ögesi, 2 tane "Edebiyat, Sanat ve Müzik" kültür ögesi, 1 tane "Kişilerarası İlişkiler"kültür ögesi ve yine 1 tane "Değerler ve Eğitim" kültür ögesi tespit edilmiştir. Bu yaklaşıma göre tespit edilen etkinliklerdeki kültür ögelerinin dağılımı, belli bir düzen veya sıraya göre yapılmamıştır. Ders kitabında yer alan yaklaşıma uygun belirlediğimiz konuşma etkinliklerinde "Günlük Yaşam”, "Sosyal Yaşam” ve "Coğrafya ve Mekân” üst kültür ögelerine rastlanılmamıştır. 
TÖS ve YİTÖS B1 ders kitaplarında, kültürlerarası iletişimsel yaklaşıma uygun içerikler belli bir düzende yer almamıştır. Yaklaşıma uygun konuşma etkinliklerinde her iki ders kitabında da 4 farklı kültür ögesine yer verilmiş, "Kişilerarası İlişkiler”, "Değerler ve Eğitim” ve "Gelenekler ve Folklor" kültür ögeleri ortak olarak yer almıştır. Belirlenen etkinliklerde her iki ders kitabında da "Sosyal Yaşam” ve "Coğrafya ve Mekân” kültür ögelerine yer verilmemiştir. Ortak olarak yer alan ve etkinliklerde yer almayan kültür ögeleri bakımından her iki ders kitabında da benzerlikler vardır.

İTÖS B2 ders kitabında belirlenmiş olan konuşma etkinlikleri çözümlenmiş ve B1 ders kitabında olduğu gibi etkinliklerin 10'unda kültürlerarası yaklaşıma uygun içerik tespit edilmiştir. Konuşma etkinlikleri incelendiğinde 5 farklı kültür ögesine rastlanılmış, etkinliklerde 3 tane "Coğrafya ve Mekân” kültür ögesi, 3 tane "Gelenekler ve Folklor" kültür ögesi, 2 tane "Edebiyat, Sanat ve Müzik" kültür ögesi, 1 tane "Kişilerarası İlişkiler” kültür ögesi ve yine 1 tane "Sosyal Yaşam" kültür ögesi tespit edilmiştir. Bu yaklaşıma göre tespit edilen etkinliklerdeki kültür ögelerinin dağılımı, belli bir düzen veya sıraya göre yapılmamıştır. Ders kitabında yer alan yaklaşıma uygun belirlediğimiz konuşma etkinliklerinde "Değerler ve Eğitim" ve "Günlük Yaşam" üst kültür ögelerine rastlanılmamıştır. Ders kitabında yer alan 6 ünitenin 6'sında da yer alan "Kültürden Kültüre" ünite sonu etkinliklerinin hepsinde kültürlerarası iletişimsel yaklaşıma uygunluk tespit edilmiştir. Bu bağlamda "Kültürden Kültüre" etkinliklerinin hepsinde kültürlerarası iletişimsel yaklaşıma ait bulguların olması, bu etkinliklerin amaca uygun şekilde tasarlandığını göstermektedir.

YİTÖS B2 ders kitabında belirlenmiş olan konuşma etkinlikleri çözümlenmiş ve etkinliklerin 11 'inde kültürlerarası yaklaşıma uygun içerik tespit edilmiştir. Konuşma etkinlikleri incelendiğinde 5 farklı kültür ögesine rastlanılmış, etkinliklerde 3 tane "Gelenekler ve Folklor" kültür ögesi, 4 tane "Kişilerarası İlişkiler" kültür ögesi, 1 tane "Değerler ve Eğitim” kültür ögesi, 1 tane "Coğrafya ve Mekân" kültür ögesi ve yine 1 tane "Edebiyat, Sanat ve Müzik" kültür ögesi tespit edilmiştir. Bu yaklaşıma göre tespit edilen etkinliklerdeki kültür ögelerinin dağılımı, belli bir düzen veya sıraya göre yapılmamıştır. Ders kitabında yer alan yaklaşıma uygun belirlediğimiz konuşma etkinliklerinde "Günlük Yaşam” ve "Sosyal Yaşam” üst kültür ögelerine rastlanılmamıştır. Ayrıca 5. Ünitedeki konuşma etkinliklerinin tamamında kültürlerarası yaklaşıma ait uygun içerik tespit edilmiştir. Bu durum, konu içeriğinin bu yaklaşıma uygun tasarlanmasıyla ilgilidir.

İTÖS ve YİTÖS B2 ders kitaplarında, kültürlerarası iletişimsel yaklaşıma uygun içerikler belli bir düzende yer almamıştır. Yaklaşıma uygun konuşma etkinliklerinde her iki ders kitabında da 5 farklı kültür ögesine yer verilmiş, "Coğrafya ve Mekân”, "Gelenekler ve Folklor", "Edebiyat, Sanat ve Müzik” ve “Kişilerarası İlişkiler” kültür ögeleri ortak olarak yer almıştır. Belirlenen etkinliklerde her iki ders kitabında da “Günlük Yaşam” kültür ögesine yer verilmemiştir. Ortak olarak yer alan ve etkinliklerde yer almayan kültür ögeleri bakımından her iki ders kitabında da benzerlikler vardır. 
Ders kitaplarında kültürlerarası iletişimsel yaklaşıma uygun içerikler, genellikle ünite başlığının içeriği destekleyecek şekilde tasarlanmasıyla şekillenmiştir. Bu nedenle bazı ünitelerde bu yaklaşıma uygun içerik tüm etkinlikleri kapsarken, bazı ünitelerde bu yaklaşıma uygun içerik hiç bulunamamıştır. "Gelenekler ve Folklor” kültür ögesi belirlenmiş ders kitaplarında örneklemi oluşturan etkinliklerde 11 defa kullanılmış ve kültürlerarası iletişimsel yaklaşıma ait etkinliklerde en sık kullanılan kültür ögesi olmuştur. "Sosyal Yaşam” ve "Coğrafya ve Mekân" kültür ögeleri ise belirlenmiş ders kitaplarında örneklemi oluşturan etkinliklerde 1 defa kullanılmış ve kültürlerarası iletişimsel yaklaşıma ait etkinliklerde en az kullanılan kültür ögeleri olmuştur. Özellikle dilin işlevselliği düşünüldüğünde “Sosyal Yaşam” kültür ögesinin az olmasının bir eksiklik olduğu söylenebilir.

İTÖS ve YİTÖS ders kitaplarında konuşma etkinlikleri incelenmiş, inceleme sonucunda kültürlerarası iletişimsel yaklaşıma uygunluğu tespit edilmiş olan konuşma etkinliklerinde kültürlerarası iletişimsel yaklaşıma uygun olan ve uygun olmayan konuşma etkinliklerine dair sayısal ve yüzdelik veriler tablo ve şekillerde belirtilmiştir. İTÖS ve YİTÖS'te yer alan ünite sayıları farklılık arz ettiği için doğru sonuçları verecek bir sayısal karşılaştırma mümkün olmamıştır. Ders kitapları arasındaki karşılaştırma yüzdelik oranlar üzerinden yapılmıştır.

İTÖS B1 ders kitabında belirlenmiş olan konuşma etkinlikleri kültürlerarası iletişime uygun içerikler yönüyle sayısal ve oransal olarak çözümlenmiş, 41 konuşma etkinliği belirlenmiş ve 10'unda örnekleme uygun içeriğe rastlanılmıştır. Bu yaklaşıma uygun etkinliklerin çoğu 6. Ünitede yer almış ve 7 etkinlikten 4 tanesinde uygun içerik tespit edilmiştir. Bu ünitede uygun etkinliğin diğer etkinliklere göre fazla olmasının sebebi olarak "İnsanlar Konuşa Konuşa” isimli ünite başlığının yaklaşıma uyumlu olması gösterilebilir. Konuşma etkinliklerinde kültürlerarası iletişimsel yaklaşıma uygun içerikler, belli bir düzende ve sayıda yerleştirilmemiştir. Ders kitabındaki konuşma etkinliklerinde kültürlerarası iletişime uygun etkinliklerin oranı ise \%24 olarak belirlenmiştir. Üniteler arasında yaklaşıma uygun etkinlik sayıları arasında bir eşitlik veya yakınlık bulunmamaktadır. Bu nedenle her ünite için ayrı değerlendirme yapılacak olursa yüzdelik oranlarda farklı sonuçlar ortaya çıkacaktır.

YİTÖS B1 ders kitabında belirlenmiş olan konuşma etkinlikleri kültürlerarası iletişime uygun içerikler yönüyle sayısal ve oransal olarak çözümlenmiş, 32 konuşma etkinliği belirlenmiş ve 7'sinde örnekleme uygun içeriğe rastlanılmıştır. Konuşma etkinlikleri incelendiğinde 1. Ünite, 4. Ünite ve 5. Ünitede kültürlerarası iletişimsel yaklaşıma uygun içerik bulunmazken 7. Ünite ve 8 . Ünitede 2 'şer adet içerik tespit edilmiştir. Bu nedenle konuşma etkinliklerinde kültürlerarası iletişimsel yaklaşıma uygun içeriklerin belli bir düzende ve sayıda olmadığı yorumlanabilir. Ders kitabındaki konuşma etkinliklerinde kültürlerarası iletişime uygun etkinliklerin oranı ise \%22 olarak belirlenmiştir. Üniteler arasında yaklaşıma uygun etkinlik sayıları arasında bir eşitlik veya yakınlık bulunmamaktadır. Bu ders kitabında da her ünite için ayrı değerlendirme yapılacak olursa yüzdelik oranlarda farklı sonuçlar ortaya çıkacaktır. 
İTÖS ve YİTÖS B1 ders kitapları incelenmiş ve yaklaşıma uygun etkinlik sayısı oranı İTÖS ders kitabında \%24, YİTÖS ders kitabında ise \%22 olarak belirlenmiştir. Ders kitaplarındaki yaklaşıma uygun etkinlik sayısı oranları arasında belirgin bir fark bulunmamaktadır. Fakat her iki ders kitabında da üniteler ayrı değerlendirildiğinde farklı sayıda yaklaşıma uygun içeriğe rastlanmıştır. Bunun sebebi ünite başlıklarının ve içeriklerinin kültürel iletişime uygunluğu etkileyebilecek olmasıdır. Bu sebeple ders kitaplarında ünite özelinde bir oranlama yapılacak olursa birbirinden farklı sonuçlar ortaya çıkacaktır.

İTÖS B2 ders kitabında belirlenmiş olan konuşma etkinlikleri kültürlerarası iletişime uygun içerikler yönüyle sayısal ve oransal olarak çözümlenmiş, 42 konuşma etkinliği belirlenmiş ve 10'unda örnekleme uygun içeriğe rastlanılmıştır. Her ünitede kültürlerarası iletişimsel yaklaşıma uygun içerik tespit edilmiştir. Bu yaklaşıma uygun etkinliklerin çoğu 1. Ünitede yer almış ve 7 etkinlikten 3 tanesinde uygun içerik tespit edilmiştir. Ünite konusunun iletişimsel yaklaşıma uyumlu olması bu durumu ortaya çıkarmıştır. Fakat konuşma etkinliklerinde kültürlerarası iletişimsel yaklaşıma uygun içerikler, belli bir düzende ve sayıda yerleştirilmemiştir. Ders kitabındaki konuşma etkinliklerinde kültürlerarası iletişime uygun etkinliklerin oranı ise \%24 olarak belirlenmiştir. Her ünite için ayrı değerlendirme yapılacak olursa yüzdelik oranlarda farklı sonuçlar ortaya çıkacaktır.

YİTÖS B2 ders kitabında belirlenmiş olan konuşma etkinlikleri kültürlerarası iletişime uygun içerikler yönüyle sayısal ve oransal olarak çözümlenmiş, 31 konuşma etkinliği belirlenmiş ve 11 'inde örnekleme uygun içeriğe rastlanılmıştır. Konuşma etkinlikleri incelendiğinde 4. Ünite ve 7. Ünitede kültürlerarası iletişimsel yaklaşıma uygun içerik bulunmazken 2. Ünitede 5 etkinlikten 3 'ünde yaklaşıma dair içeriğe rastlanılmıştır. Bu açıdan bakıldığında konuşma etkinliklerinde kültürlerarası iletişimsel yaklaşıma uygun içeriklerin, belli bir düzende ve sayıda yerleştirilmediği söylenebilir. Ders kitabındaki konuşma etkinliklerinde kültürlerarası iletişime uygun etkinliklerin oranı ise \%35 olarak belirlenmiştir. Üniteler arasında yaklaşıma uygun etkinlik sayıları arasında bir eşitlik veya yakınlık bulunmamaktadır. Bu nedenle bu ders kitabında da her ünite için ayrı değerlendirme yapılacak olursa yüzdelik oranlarda birbirinden uzak sonuçlar ortaya çıkacaktır.

İTÖS ve YİTÖS B2 ders kitapları incelenmiş ve yaklaşıma uygun etkinlik sayısı oranı İTÖS ders kitabında \%24, YİTÖS ders kitabında ise \%35 olarak belirlenmiştir. Ders kitaplarındaki yaklaşıma uygun etkinlik sayısı oranları arasında belirgin bir fark ortaya çıkmıştır. YİTÖS ders kitabındaki bu yüksek oran, ünitelerin kültürlerarası iletişime uygun içeriği fazlaca barındırmasıyla ilgilidir. Ayrıca her iki ders kitabında üniteler ayrı değerlendirildiğinde farklı sayıda yaklaşıma uygun içeriğe rastlanmıştır. Bunun sebebi de ünite başlıklarının ve içeriklerinin kültürel iletişime uygunluğu etkileyebilecek olmasıdır. Bu sebeple ünite özelinde bir oranlama yapılacak olursa birbirinden farklı sonuçlar ortaya çıkacaktır. 
Ders kitaplarına genel olarak bakıldığında, yaklaşıma uygun etkinlik oranları bakımından YİTÖS B2 ders kitabında \%35'lik bir oran olması nedeniyle bariz bir fark görülmektedir. YİTÖS B1 ders kitabında ise bu oran \%22'de kalmıştır. İTÖS B1 ve B2 ders kitaplarının her ikisinde de bu oran \%24 olarak ortaya çıkmıştır. İTÖS ders kitapları, hem kültülerarsı iletişime uygun etkinliklerdeki kültür oranlarının dağılımı, hem de etkinlik sayılarının oranı bakımından daha düzenli ve sistematik şekilde tasarlanmıştır. İTÖS ders kitaplarında "Kültürden Kültüre" bölümleri bu oranları ve dağılımları olumlu yönde etkilemiştir.

Araştırma sonuçlarına bakılarak aşağıdaki öneriler sunulmuştur.

Yabancı dil öğrenmek, aynı zamanda kültür alışverişinde bulunmayı gerektirir. Dili öğrenen, öğrendiği dili sosyal yaşamda kullanmalı ve hedef kültürle bir bağ kurabilmelidir. Bu bağlamda dili tam öğrenmek için kültürlerarası iletişimsel yeterliği sağlamak gerekmektedir. Bu amacı gerçekleştirmek için öğrenci, öğretim görevlisi ve ders kitabı yazarlarına ayrı ayrı sorumluluk düşmektedir.

Yabancı dil öğretiminde öğrencinin kültür alış verişini sağlamak için yeterli düzeyde materyal kullanılmalı, materyallerde kültür ögeleri belli bir düzen ve sayıda yer almalıdır. Ayrıca bu ögelerin tamamı etkinliklerin geneline yayılmalıdır. Kültür ögeleri verilirken kültürlerarası iletişimsel yaklaşıma uygun içerikler tasarlanmalı ve öğrenciler, uygulamaları nerede kullanacakları yönünde bilinçlendirilmelidir.

Ders kitaplarında kültür aktarımı yapılırken temel seviyelerde (A1 ve A2) sadece hedef kültüre yönelik basit uygulamalarla farkındalık oluşturmak amaçlanmalı ve öğrenciye tek taraflı kültür aktarımı yapılmamalıdır. Hedef kültüre ait karmaşık yapıdaki kültür ögeleri orta seviyeden (B1 ve B2) başlayarak verilmeli ve ileri seviyelere doğru arttırılmalıdır.

Günlük yaşamda karşılaşılması güç olan veya tartışmalı durumlara yönelik uygulamalardan uzak durulmalıdır. Daha çok öğrencinin işine yarayacak ve günlük yaşamda kolaylık sağlayacak uygulamalara yer verilmelidir. Kültürlerarası yeterliğin kazandırılması için kültür ögelerinin kaynak kültürü de destekleyecek nitelikte aktarılması gerekmektedir.

Hakem Değerlendirmesi: Dış bağımsız.

Çıkar Çatışması: Yazar çıkar çatışması bildirmemiştir.

Finansal Destek: Yazar bu çalışma için finansal destek almadığını beyan etmiştir.

Peer-review: Externally peer-reviewed.

Conflict of Interest: The author has no conflict of interest to declare.

Grant Support: The author declared that this study has received no financial support. 


\section{Kaynaklar/References}

Avrupa Konseyi/Modern Diller Bölümü. Diller İçin Avrupa Ortak Öneriler Çerçevesi Öğrenim, Öğretim ve Değerlendirme, 2013. Erişim 4 Ocak 2021, https://www.telc.net/fileadmin/user_upload/Publikationen/ Diller_iain_Avrupa_Ortak_oneriler_AEeraevesi.pdf

Barın, Erol, Şaban Çobanoğlu, Şeref Ateş, Mustafa Balcı, Cihan Özdemir (ed.). Yunus Emre Enstitüsü Türkçe Öğretim Seti B1 Ders Kitabı. Ankara: Merdiven Reklam Tanıtım, 2015.

Barın, Erol, Şaban Çobanoğlu, Şeref Ateş, Mustafa Balcı, Cihan Özdemir (ed.). Yunus Emre Enstitüsü Türkçe Öğretim Seti B2 Ders Kitabı. Ankara: Merdiven Reklam Tanıtım, 2015.

Boylu, Emrah. "Dil-Kültür İlişkisi ve İranda Türkçe Öğretime Etkisi”, Karamanolu Mehmet Bey Üniversitesi Sosyal ve Ekonomik Aratırmalar Dergisi 4 (2014): 19-28.

Bölükbaş, Fatma, Mehmet Y. Yılmaz (Ed.). İstanbul Yabancılar İçin Türkçe B1 Ders Kitabı. İstanbul: Kültür Sanat, 2017.

Bölükbaş, Fatma, Mehmet Y. Yılmaz (Ed.). İstanbul Yabancılar İçin Türkçe B2 Ders Kitabı. İstanbul: Kültür Sanat, 2017.

Demir, Ahmet, Açık, Fatma. “Türkçenin Yabancı Dil Olarak Öğretiminde Kültürlerarası Yaklaşım Ve Seçilecek Metinlerde Bulunması Gereken Özellikler”, Türklük Bilimi Araştırmaları 30 (2011): 51-72.

Doğan, Yusuf. "Konuşma Becerisinin Geliştirilmesine Yönelik Etkinlik Önerileri”, Türk Eğitim Bilimleri Dergisi 7/1 (2009): 185-204.

Göçer, Ali. “Türkçenin Yabancı Dil Olarak Öğretiminde Konuşma Becerisinin Kazandırılması”, Trakya Üniversitesi Sosyal Bilimler Dergisi 17/2 (2015): 21-36.

Gürsoy, Serdar, Güleç, İsmail. "Yabancılara Türkçe Öğretiminde Kültürel Ögelerin Aktarımı: Gökkuşağı Türkçe Öğretim Seti Temel Seviye Örneği”, IV. Sakarya'da Eğitim Araşstırmaları Kongresi Bildiri Kitabriçinde, 98-119.Sakarya (2015).

Güzel, Abdurrahman, Barın, Erol. Yabancı dil olarak Türkçe öğretimi. Ankara: Akçağ Yayınları, 2013

İltar, Latif. Türkçenin yabancı dil olarak öğretiminde kullanılan ders kitaplarındaki okuma metinlerinin farklı değişkenler açısından değerlendirilmesi. Doktora tezi, Gazi Üniversitesi, 2018.

İltar, Latif. «Dil Edinimi, Dil Öğrenimi/Öğretimi ve Dil Eğitimi Üzerine Tartışmalar», Boylu, Emrah, İltar Latif. (Ed.) Yabancı Dil Olarak Türkçe Öğretimi Politika, Program, Yöntem ve Öğretim içinde, 1-26. Ankara: PEGEM, 2019.

İltar, Latif. «Kültürlerarası İletişimsel Dil Yeterliği Bağlamında Göçmenlere Türkçe Öğretimi», Başar, Umut, Tüfekçioğlu Burak. (Ed.) Göçmelere Türkçeöğretimi içinde, 45-66. Ankara: Nobel. 2020.

İşcan, Adem, Yassıtaş, Tufan. «Yabancı dil olarak Türkçe öğretimi ders kitaplarında kültür aktarımı: Yedi iklim Türkçe öğretim seti örneği (B1-B2 düzeyi)», Aydın Tömer Dil Dergisi 3/1 (2018): 47-66.

Kalenderoğlu, İhsan. "Türkçenin Yabancı Dil Olarak Öğretiminde Kullanılan Temel Düzey (A1, A2) Ders Kitaplarında Kültür Aktarımı”, 21. Yüzyllda Eğitim ve Toplum Eğitim Bilimleri ve Sosyal Araştırmalar Dergisi 4/12 (2015): 73-83.

Kara Özkan, Neşe. "Yabancı Di Olarak Türkçede Kelime Öğretimi Üzerine Bir Değerlendirme”, Baytarek Uluslararası Akademik Araştırmalar Dergisi 3/2 (2020): 126-139.

Korkmaz, Cihat Burak. "Yumuşak Güç Kaynağı Bağlamında Yabancı Dil Olarak Türkçenin Öğretimi”, Bayterek Uluslararası Akademik Araştırmalar Dergisi 3/2 (2020): 74-95, erişim 1 Ocak 2021, DOI:10.48174/ buaad. 820640 
Kurudayıŏlu, Mehmet. "Konuşma Eğitimi ve Konuşma Becerisini Geliştirmeye Yönelik Etkinlikler” TÜBARXIII, (2003): 287-309.

Nurlu, Muammer. Türkçenin Yabancı Dil Olarak Öğretimi. Ankara: Kalem Kitap Yayınevi, 2019

Okur, Alparslan, Keskin, Funda. "Yabancılara Türkçe öğretiminde kültürel ögelerin aktarımı: İstanbul Yabancılar İçin Türkçe Öğretim Seti Örneği”, International Journal of Social Science Volume 6 Issue 2 6/2 (2013): 1619-1640.

Temizkan, Mehmet. “Akran Değerlendirmenin Konuşma Becerisinin Geliştirilmesi Üzerindeki Etkisi”, Mustafa Kemal Üniversitesi Sosyal Bilimler Enstitüsü Dergisi 6/12 (2009): 90-112.

Temizyürek, Fahri. "İlköğretim ikinci kademede konuşma becerisinin geliştirilmesi” Ankara Üniversitesi Ĕgitim Bilimleri Fakültesi Dergisi 40/2 (2007): 113-131.

Uyar, Yusuf. Türkçe Öğretiminde Kültür Aktarımı ve Kültürel Kimlik Geliştirme. Yüksek lisans tezi, Gazi Üniversitesi, 2007. 
